\title{
Novel Pathology-Related Hub Genes in Focal Segmental Glomerulosclerosis
}

\author{
Qianhong $\mathrm{Ma}^{1}$, Dongmei Zhang ${ }^{2}$ and Zhongying Huang ${ }^{1 *}$ \\ ${ }^{1}$ West China Second Hospital, Sichuan University, Key Laboratory of Birth Defects and Related Diseases of Women and Children, Ministry of Education, \\ Chengdu, Sichuan, China \\ ${ }^{2}$ Southwest Medical University, Luzhou, Sichuan, China
}

${ }^{*}$ Corresponding author: Zhongying Huang, West China Second Hospital, Sichuan University, Chengdu, Sichuan, Zipcode: 610041, China; Tel: 86-28-85501650; Email: huangzyhxyd@scu.edu.cn

Received: October 29, 2019; Accepted: November 11, 2019; Published: November 15, 2019;

\begin{abstract}
Objectives: Focal Segmental Glomerulosclerosis (FSGS) is a progressive glomerular disease. The pathogenesis of this disease, however, remains unclear. Here, we attempted to identify key candidate genes in FSGS through stringent bioinformatic analysis.

Methods: We systematically searched the Gene Expression Omnibus database for gene expression microarrays derived from human glomeruli tissues with FSGS. First, we identified differentially expressed genes (DEGs) by using the Limma package in R. Then, we subjected these DEGs to Gene Ontology (GO) analysis for further analysis. Finally, we constructed Protein-Protein Interaction networks (PPI) through four different methods and performed intersection analysis to further refine our results.

Results: A total of 627 DEGs were identified between the FSGS and control groups, among which 534 were up-regulated and 93 were down-regulated. GO analysis revealed that the DEGs were enriched in mRNA processing, cell adhesion molecule binding, and cadherin binding. Furthermore, via PPI, 7 DEGs overlapped in the four groups constructed through different analytical approaches. We also validated the overlapped 7 hub genes in in vitro experiments, including RBM5 and HNRNPF, with potentially important roles in the development of FSGS.
\end{abstract}

Conclusion: Our study provides a valuable resource for novel biomarkers and therapeutic targets for FSGS.

Keywords: Focal segmental glomerulosclerosis; Bioinformatic analysis; RBM5; HNRNPF

\section{Introduction}

Focal Segmental Glomerulosclerosis (FSGS) is a primary glomerular disease that manifests with heavy proteinuria [1]. It is the leading cause of the development of end-stage renal disease. Typically, FSGS lesions present a segmental manifestation that includes parietal cell migration, hyaline deposition, capillary collapse, and intracapillary thrombi. Recent studies suggest that podocyte injury may play a key role in FSGS lesions [2]. Injury and loss of podocytes result in foot process effacement and protein loss [3]. However, the pathogenesis of FSGS remains unclear, and the present diagnostic and therapeutic methods for this disease remain inadequate. Oxidative stress has been implicated in the development and progression of this FSGS [4,5]. Nuclear factor E2-related factor 2 (Nrf2) is a transcription factor that can potently induce the production of numerous antioxidants and prevent the generation of oxidative stress in renal fibrosis and inflammation [6-8]. Furthermore, apoptosis and the reninangiotensin system are strongly involved in FSGS-related injury [9-12]. Nevertheless, a considerable amount of important FSGS genes remain unidentified given the lack of global analysis.

With the development of bioinformatic analysis technology, gene expression profiling analysis has been increasingly used to explore molecular mechanisms and identify novel biomarkers in various diseases [13-16]. Bioinformatic analysis is mainly used to predict novel diagnostic biomarkers and therapeutic targets associated with tumors, such as bladder cancer [17], meningioma [18], and hepatocellular carcinoma [19]. The application of bioinformatic analysis in renal diseases, such as renal cell carcinoma [20], lupus nephritis [21], IgA nephropathy [22], and chronic kidney disease [23], has begun to develop gradually. However, up to now, no study has subjected FSGS to bioinformatic analysis. Thus, exploring the underlying crucial genes and effective therapeutic targets for FSGS through bioinformatic analysis is necessary.

In this study, we downloaded the gene expression profile datasets of FSGS from the Gene Expression Omnibus (GEO) database and investigated Differentially Expressed Genes (DEGs) between FSGS and control samples by using the Limma package in R. We performed Gene Ontology (GO) enrichment analysis for all DEGs. In addition, we constructed protein-protein interaction (PPI) networks, identified novel hub genes, and validated them in in vitro experiments. Our study aimed to predict novel diagnostic biomarkers and potential therapeutic targets for FSGS. 


\section{Materials and Methods}

\section{Data collection}

Gene expression profiles were retrieved from NCBI's GEO database (http://www.ncbi.nlm.nih.gov/geo/) by using the key words "focal segmental glomerulosclerosis" with the following criteria: 1) the study type is expression profiling by array, 2) the attribute name is tissue, 3) the organism of interest is Homo sapiens, and 4) the platform used is the Affymetrix Human Genome U133A Array. Ultimately, on the basis of the above criteria, we selected dataset GSE47185 of FSGS. Original CEL files were used for further bioinformatic analysis.

\section{Data preprocessing}

CEL files were normalized and converted to expression profiles by using the Affy package of $\mathrm{R}$ [24]. In brief, the original data were read using the Affy Bioconductor package and preprocessed for normalization through the robust multiarray analysis method, which includes background correction, normalization, expression calculation and batch effects removal. After obtaining the gene expression value, genes were annotated with the hgu133A.db and annotate software packages.

\section{DEG analysis}

The Limma package of $\mathrm{R}$ [25] was used to analyze DEGs after preprocessing. The linear fit method, Bayesian analysis, and $t$-test algorithm were used to calculate the $\mathrm{P}$ and FC values. DEGs were screened by setting a cut-off value of $\mid \log 2$ Fold Change (FC) $\mid>1$ and $\mathrm{P}<0.05$. The ggplot 2 software package was used to visualize results. Moreover, to identify and visualize the DEGs between FSGS and normal samples, we generated a heat map of the top $10 \%$ DEGs by using the heatmap package (Version 1.0.8).

\section{GO enrichment analysis for DEGs}

The GO consortium includes three independent branches: Biological Process (BP), Cellular Component (CC), and Molecular Function (MF). In this study, we subjected the identified DEGs to GO enrichment analysis by using $\mathrm{R}$ and the clusterProfiler package [26]. $\mathrm{P}<0.05$ was used as the threshold for the identification of significant GO terms.

\section{PPI Network Construction}

To explore the relationships among the top 30\% DEGs, we used the online tool STRING (Search Tool for the Retrieval of Interacting Genes/Proteins; http://string.embl.de/) database for the construction of PPI networks. The minimum required interaction score of 0.4 was used as the significant cut-off threshold. Then, the obtained PPI interaction networks were visualized by using Cytoscape software (version 6.3).

\section{Hub-gene screening}

On the basis of the STRING results, we introduced the four methods Degree, EPC, Maximal Clique Centrality (MCC), and DMNC [27] to rank the importance of nodes in the PPI networks and to further identify hub genes from the top 30\% DEGs. Nodes with high centrality scores were considered hub genes. We applied the $\mathrm{R}$ package Venn diagram (version1.6.17, https://cran.r-project.org/web/ packages/VennDiagram/) [28] to identify overlapping DEGs among these hub genes.

Degree $(\operatorname{Deg}(\mathrm{v})=|\mathrm{N}(\mathrm{v})|)$ is a computing tool in Cytoscape software [29]. The default filter "in and out" was between 7 and 42 in the present study.

MCC is a topological analysis method in CytoHubba [27]. Given a node $\mathrm{v}$, the MCC of $\mathrm{v}$ is defined as $\mathrm{MCC}(\mathrm{v})=\Sigma \mathrm{C} \in \mathrm{S}(\mathrm{v})(|\mathrm{C}|-1)$ !.

Maximum Neighborhood Component (MNC) is another computing tool in cytoHubba. $\mathrm{MNC}(\mathrm{v})=|\mathrm{V}(\mathrm{MC}(\mathrm{v}))|$, where $\mathrm{MC}(\mathrm{v})$ is a maximum connected component of $\mathrm{G}[\mathrm{N}(\mathrm{v})]$, and $\mathrm{G}[\mathrm{N}(\mathrm{v})]$ is the induced subgraph of $\mathrm{G}$ by $\mathrm{N}(\mathrm{v})$. On the basis of MNC, Lin et al. proposed that $\mathrm{DMNC}(\mathrm{v})=|\mathrm{E}(\mathrm{MC}(\mathrm{v}))| /|\mathrm{V}(\mathrm{MC}(\mathrm{v}))| \varepsilon$, where $\varepsilon=1.7$.

\section{Cell culture}

Conditionally immortalized human podocytes (LY893) were kindly provided by Dr. Lan Ni and Moin Saleem(Bristol, U.K.). Podocytes were cultured in RPMI 1640 medium(Gibco)supplemented with $10 \%$ Fetal Bovine Serum (Gibco) and 1\% Insulin-TransferrinSelenium(Invitrogen) at $33^{\circ} \mathrm{C}$ under $5 \% \mathrm{CO} 2$ for propagation, then were thermo switched to $37^{\circ} \mathrm{C}$ under $5 \% \mathrm{CO} 2$ when at $60 \%$ confluency for differentiation. The differentiated podocytes were incubated with adriamycin to construct an in vitro model for FSGS [30].

\section{Quantitative Real-Time PCR}

Total RNA was extracted using the RNeasy Plus Mini Kit (BioTeke RP1202) in accordance with the manufacturer's instructions. The CDNA was obtained by reverse transcription, amplified and detected using a SYBR Green Supermix kit (Takara). Then, a BIO-RAD CFX96 Real-Time PCR system (Bio-Rad) was used for PCR analysis under the following conditions: $95^{\circ} \mathrm{C}$ for $3 \mathrm{~min}$, followed by 40 cycles of 95 ${ }^{\circ} \mathrm{C}$ for $10 \mathrm{~s}$ and $51{ }^{\circ} \mathrm{C}$ for $30 \mathrm{~s}$. The primer sequences used for PCR are listed in Table 1. Statistical differences were determined by Student's t-test using $\mathrm{R}$ "ggpubr" package(version 0.1.8, https://CRAN.Rproject.org/package=ggpubr).

\section{Results}

\section{DEGs identification}

This dataset GSE47185 contains the mRNA expression profiles of 13 FSGS samples and 14 control samples (normal tissue of renal tumor excision). Under the threshold of $\mid \log 2$ fold change (FC) $\mid>1$ and adj.P value $<0.05,627$ DEGs were identified between the FSGS and control groups. These DEGs included 534 up-regulated and 93 downregulated DEGs. The results of expression-level analysis are presented as a volcano plot in Fig. 1A. As shown in Table 2, RPS4Y1, PLPP3, DDX3Y, SART3, TCF4, TROVE2, IQGAP1, MBP, CALD1, and RBFOX2 are the 10 most significantly up-regulated genes, whereas CYP4A11, FOSB, EGR1, G6PC, ALB, CTSZ, PPP3R1, XIST, PCK1, and HPGD are the 10 most significantly down-regulated genes. The more information of all DEGs is listed in supplementary Table 1.

The heatmaps of the top 10\% DEGs are shown in Fig. 1B. The data are presented in a matrix format, in which rows represent individual 
genes, and columns represent individual samples. The purple and green colors indicate up-regulated and down-regulated genes, respectively. The hierarchy cluster analysis indicated that FSGS and control groups could be distinguished from each other on the basis of their different expression patterns.

\section{Functional enrichment analysis}

To reveal the biological functions of DEGs, we used the clusterProfiler package for GO analysis. We set adj.P value $<0.01$ to identify significantly enriched GO terms. The top eight GO terms for the DEGs enriched in the BP, CC, and MF are shown in Figure 2.The DEGs were mainly involved in GO terms that included mRNA processing, regulation of mRNA metabolic process, antigen processing and presentation of exogenous antigen, focal adhesion, cell adhesion molecule binding, cadherin binding, and actin binding. Among these terms, the MFs related to focal adhesion (GO:0005925) [31,32], cell adhesion molecule (GO:0050839) [33,34], cadherin (GO:0045296) [35], and actin binding (GO:0003779) [36] were all confirmed to be involved in glomerulosclerosis. Detailed information on the top eight GO terms is shown in Table 3 .

Table 1. Primer sequences for RT-PCR.

\begin{tabular}{|l|l|l|}
\hline \multicolumn{1}{|c|}{ Gene } & \multicolumn{1}{|c|}{ Forward primer } & \multicolumn{1}{c|}{ Reverse primer } \\
\hline FUS & 5' GCAGGAGTTTGTGGAGTG 3' & 5' TGAGTACAGGCAGGATGTG 3' \\
\hline DHX15 & 5' CTTTACAAGCAGGGACTA 3' & 5' TCAAGAACAGTAGAGGGAT 3' \\
\hline PRPF31 & 5' TGTCGGGCTTCTCGTCTA 3' & 5' CACCTTCCCTTCTGTGCTCT 3' \\
\hline PQBP1 & 5' CAAGAAGGCAGTAAGCCGAAAG 3' & 5' TGTGGTGTCAGCGCCAGTC 3' \\
\hline RBM5 & 5' GGTGCGAAATGGAGATGA 3' & 5' AGAGTTGCTGGTGCCTGA 3' \\
\hline HNRNPR & 5' AAGTCCCACAGAACCGAGAT 3' & 5' AACCCTGAGAAGAACTGAACAA 3' \\
\hline TRA2B & 5' CACATACGCCAACACCAG 3' & 5' TCCTCCACCTCCTCCTCT 3' \\
\hline GAPDH & 5' CTTTGGTATCGTGGAAGGACTC 3' & 5' GTAGAGGCAGGGATGATGTTCT 3' \\
\hline
\end{tabular}

A

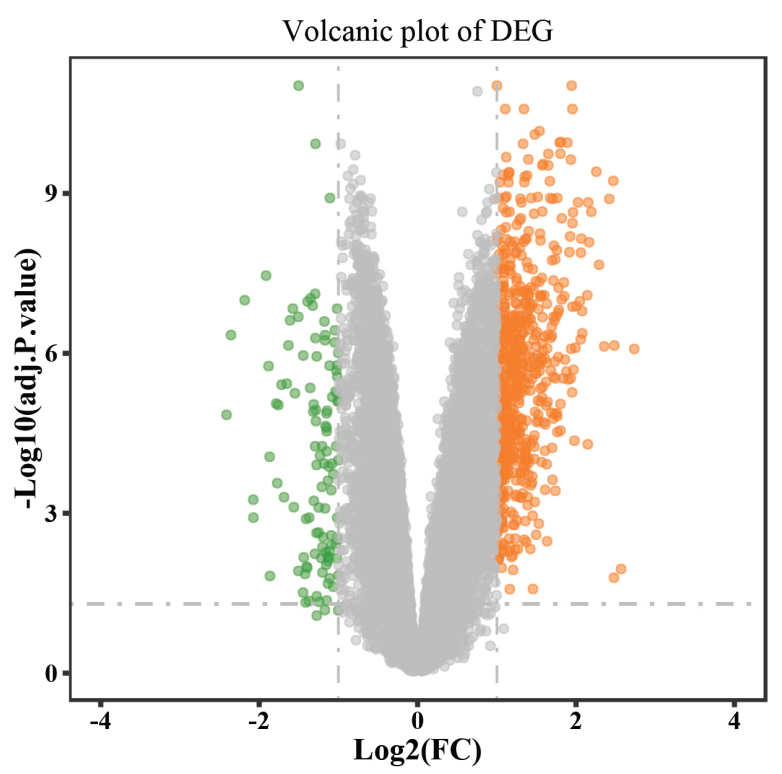

B

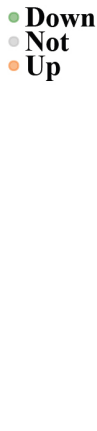

Figure 1. Visualization of DEGs

A, The volcano plot of differentially expressed genes between FSGS and healthy tissues. The red plots represent up-regulated genes, green plots represent down-regulated genes, while grey plots represent non-significant genes. The volcano plot was constructed using the ggplot2 package of the R language; B, A heatmap of the top $10 \%$ DEGs. The horizontal axis denotes the different samples, and the vertical axis denotes different DEGs.blue, normal samples; red, FSGS samples; purple clusters represent up-regulated DEGs and green clusters represent downregulated DEGs. Color key represents the Z-score based on the Gene expression value. 


\section{The Most Enriched GO Terms}

RNA splicing, via transesterification reactions with bulged... mRNA splicing, via spliceosome RNA splicing, via transesterification reactions RNA splicing regulation of mRNA metabolic process mRNA processing

antigen processing and presentation of exogenous antigen -

antigen processing and presentation of exogenous peptide ant...

$\stackrel{5}{\stackrel{5}{\Phi}}$

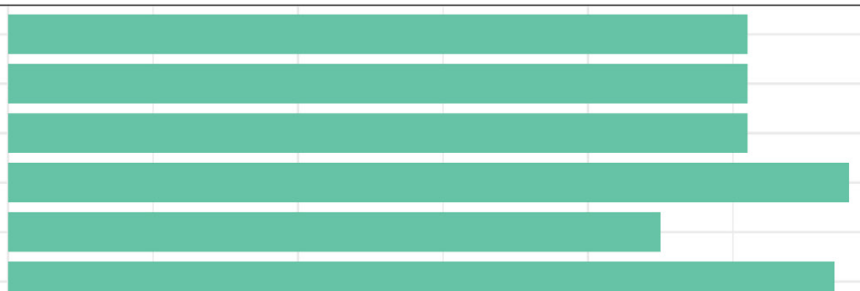
spliceosomal complex MHC protein complex

$$
\text { focal adhesion }
$$
cell-substrate adherens junction cell-substrate junction catalytic step 2 spliceosome endocytic vesicle membrane integral component of lumenal side of endoplasmic reticulum...

peptide antigen binding cell adhesion molecule binding peptide binding amide binding cadherin binding actin binding threonine-type endopeptidase activity threonine-type peptidase activity -

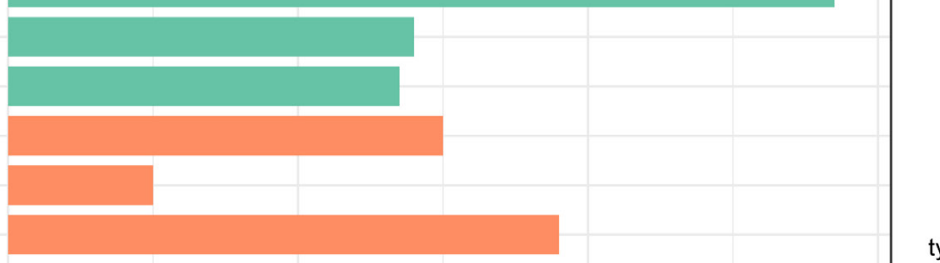

type

molecular function cellular component

biological process

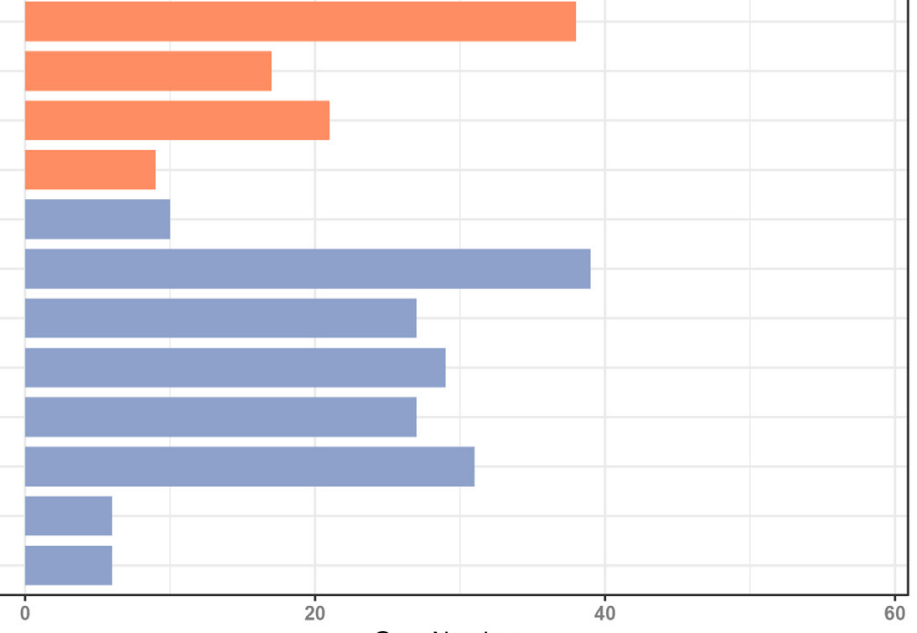

Figure 2. The 8 most significant enriched GO terms of DEGs

The adj.P value $<0.01$ was used as the threshold for the identification of significant GO terms. The Gene ontology covers the biological process, cellular component, and molecular function. The horizontal axis represents the gene counts, the vertical axis represents GO terms. Green column graphs represent biological process(BP) GO term; orange column graphs represent cellular component(CC) GO term; and blue column graphs represent molecular function (MF) GO term.

Table 2. The Most Significant 10 Up-Regulated Genes And Down-Regulated Genes.

\begin{tabular}{|l|c|c|c|}
\hline Gene Symbols & Log FC & $\begin{array}{c}\text { Average Expression } \\
\text { level }\end{array}$ & Adj.P. Value \\
\hline RPS4Y1 & 2.569009 & 9.570289 & $1.11 \mathrm{E}-02$ \\
\hline PLPP3 & 2.485089 & 9.251834 & $7.13 \mathrm{E}-07$ \\
\hline DDX3Y & 2.478844 & 7.003028 & $1.62 \mathrm{E}-02$ \\
\hline SART3 & 2.470577 & 7.660357 & $5.82 \mathrm{E}-10$ \\
\hline TCF4 & 2.41899 & 7.335133 & $1.27 \mathrm{E}-09$ \\
\hline TROVE2 & 2.355365 & 9.457713 & $7.39 \mathrm{E}-07$ \\
\hline IQGAP1 & 2.290646 & 8.145384 & $2.19 \mathrm{E}-08$ \\
\hline MBP & 2.255968 & 7.587945 & $3.91 \mathrm{E}-10$ \\
\hline CALD1 & 2.192563 & 8.074506 & $2.21 \mathrm{E}-09$ \\
\hline RBFOX2 & 2.164463 & 8.698168 & $8.22 \mathrm{E}-09$ \\
\hline
\end{tabular}

\begin{tabular}{|l|c|c|c|}
\hline Gene Symbols & Log FC & $\begin{array}{c}\text { Average Expression } \\
\text { level }\end{array}$ & Adj.P. Value \\
\hline CYP4A11 & -2.41227 & 9.128665 & $1.42 \mathrm{E}-05$ \\
\hline FOSB & -2.35626 & 8.074382 & $4.53 \mathrm{E}-07$ \\
\hline EGR1 & -2.18278 & 10.28014 & $1.01 \mathrm{E}-07$ \\
\hline G6PC & -2.07454 & 6.566343 & $5.57 \mathrm{E}-04$ \\
\hline ALB & -2.0735 & 9.571928 & $1.21 \mathrm{E}-03$ \\
\hline CTSZ & -1.91281 & 8.256097 & $3.49 \mathrm{E}-08$ \\
\hline PPP3R1 & -1.88153 & 7.627366 & $1.74 \mathrm{E}-06$ \\
\hline XIST & -1.86386 & 7.615666 & $1.50 \mathrm{E}-02$ \\
\hline PCK1 & -1.7723 & 10.99439 & $2.73 \mathrm{E}-04$ \\
\hline HPGD & -1.7174 & 10.07267 & $3.87 \mathrm{E}-06$ \\
\hline
\end{tabular}


Table 3. The Most Significantly Enriched GO Terms In BP ,CC and MF.

\begin{tabular}{|c|c|c|c|c|}
\hline ID & Description & Adj.P.Value & Gene ID & Category \\
\hline GO:0000377 & $\begin{array}{l}\text { RNA splicing, via } \\
\text { transesterification } \\
\text { reactions with bulged } \\
\text { adenosine as nucleophile }\end{array}$ & $1.19 \mathrm{E}-16$ & $\begin{array}{l}\text { SART3/RBFOX2/LUC7L3/HNRNPF/DDX17/SON/RBM5/DHX15/SCAF11/HNRNPM/FUS/ } \\
\text { RBM25/MBNL2/HNRNPR/PRPF31/TRA2B/PQBP1/HNRNPD/SRRM2/DDX39A/DDX41/ } \\
\text { DHX9/SRSF3/TIA1/HNRNPA2B1/PNN/PRPF4B/HNRNPC/JMJD6/SRRM1/SYNCRIP/ } \\
\text { DNAJC8/SNRPB/PAPOLA/METTL3/SRSF7/SF3B4/GPKOW/C1QBP/DHX35/CSTF1/SART1/ } \\
\text { RBM8A/LSM4/USP39/POLR2E/PRPF19/SRPK2/HNRNPA3/PRMT5/POLR2A }\end{array}$ & $\mathrm{BP}$ \\
\hline GO:0000398 & $\begin{array}{l}\text { mRNA splicing, via } \\
\text { spliceosome }\end{array}$ & $1.19 \mathrm{E}-16$ & $\begin{array}{l}\text { SART3/RBFOX2/LUC7L3/HNRNPF/DDX17/SON/RBM5/DHX15/SCAF11/HNRNPM/FUS/ } \\
\text { RBM25/MBNL2/HNRNPR/PRPF31/TRA2B/PQBP1/HNRNPD/SRRM2/DDX39A/DDX41/ } \\
\text { DHX9/SRSF3/TIA1/HNRNPA2B1/PNN/PRPF4B/HNRNPC/JMJD6/SRRM1/SYNCRIP/ } \\
\text { DNAJC8/SNRPB/PAPOLA/METTL3/SRSF7/SF3B4/GPKOW/C1QBP/DHX35/CSTF1/SART1/ } \\
\text { RBM8A/LSM4/USP39/POLR2E/PRPF19/SRPK2/HNRNPA3/PRMT5/POLR2A }\end{array}$ & $\mathrm{BP}$ \\
\hline GO:0000375 & $\begin{array}{l}\text { RNA splicing, via } \\
\text { transesterification } \\
\text { reactions }\end{array}$ & $1.20 \mathrm{E}-16$ & $\begin{array}{l}\text { SART3/RBFOX2/LUC7L3/HNRNPF/DDX17/SON/RBM5/DHX15/SCAF11/HNRNPM/FUS/ } \\
\text { RBM25/MBNL2/HNRNPR/PRPF31/TRA2B/PQBP1/HNRNPD/SRRM2/DDX39A/DDX41/ } \\
\text { DHX9/SRSF3/TIA1/HNRNPA2B1/PNN/PRPF4B/HNRNPC/JMJD6/SRRM1/SYNCRIP/ } \\
\text { DNAJC8/SNRPB/PAPOLA/METTL3/SRSF7/SF3B4/GPKOW/C1QBP/DHX35/CSTF1/SART1/ } \\
\text { RBM8A/LSM4/USP39/POLR2E/PRPF19/SRPK2/HNRNPA3/PRMT5/POLR2A }\end{array}$ & $\mathrm{BP}$ \\
\hline GO:0008380 & RNA splicing & $2.97 \mathrm{E}-16$ & $\begin{array}{l}\text { SART3/RBFOX2/LUC7L3/HNRNPF/DDX17/SON/RBM5/DHX15/PPIG/SCAF11/HNRNPM/ } \\
\text { FUS/RBM25/MBNL2/HNRNPR/PRPF31/TRA2B/PQBP1/HNRNPD/SRRM2/DDX39A/DDX41/ } \\
\text { DHX9/SRSF3/TIA1/AKAP8L/LGALS3/HNRNPA2B1/PNN/PRPF4B/HNRNPC/JMJD6/ } \\
\text { SRRM1/RRAGC/SYNCRIP/DNAJC8/SNRPB/WT1/IK/PAPOLA/METTL3/SRSF7/SF3B4/ } \\
\text { GPKOW/C1QBP/DHX35/TMBIM6/CSTF1/SART1/RBM8A/LSM4/USP39/POLR2E/PRPF19/ } \\
\text { SRPK2/HNRNPA3/PRMT5/POLR2A }\end{array}$ & BP \\
\hline GO:1903311 & $\begin{array}{l}\text { regulation of mRNA } \\
\text { metabolic process }\end{array}$ & $2.24 \mathrm{E}-15$ & $\begin{array}{l}\text { RBFOX2/DDX17/SON/RBM5/PSMA7/PSMB8/RBM25/PSMC3/TNPO1/SERBP1/MBNL2/ } \\
\text { HNRNPR/YWHAB/TRA2B/SET/HNRNPD/PSMA3/PUM1/PSMB4/DHX9/EIF4G1/SRSF3/ } \\
\text { PSMD4/TIA1/PSMD13/AHCYL1/HNRNPA2B1/HNRNPC/JMJD6/PSME3/PSMB9/SYNCRIP/ } \\
\text { PAPOLA/METTL3/SRSF7/SF3B4/C1QBP/CNOT8/TMBIM6/RBM8A/BTG2/PRPF19/PSMB10/ } \\
\text { SRPK2/ZFP36 }\end{array}$ & $\mathrm{BP}$ \\
\hline GO:0006397 & mRNA processing & $5.38 \mathrm{E}-13$ & $\begin{array}{l}\text { SART3/RBFOX2/LUC7L3/HNRNPF/DDX17/SON/RBM5/DHX15/SCAF11/HNRNPM/FUS/ } \\
\text { RBM25/MBNL2/HNRNPR/PRPF31/TRA2B/PQBP1/HNRNPD/SRRM2/DDX39A/DDX41/ } \\
\text { DHX9/SRSF3/TIA1/AKAP8L/AHCYL1/LGALS3/HNRNPA2B1/PNN/PRPF4B/HNRNPC/ } \\
\text { JMJD6/SRRM1/SYNCRIP/DNAJC8/SNRPB/IK/PAPOLA/METTL3/SRSF7/SF3B4/GPKOW/ } \\
\text { C1QBP/DHX35/TMBIM6/CSTF1/CHTOP/SART1/RBM8A/LSM4/USP39/POLR2E/PRPF19/ } \\
\text { SRPK2/HNRNPA3/PRMT5/POLR2A }\end{array}$ & $\mathrm{BP}$ \\
\hline GO:0019884 & $\begin{array}{l}\text { antigen processing } \\
\text { and presentation of } \\
\text { exogenous antigen }\end{array}$ & $1.68 \mathrm{E}-08$ & $\begin{array}{l}\text { HLA-DRA/DYNC1LI2/HLA-DQB1/HLA-B/PSMA7/HLA-DPA1/PSMB8/PSMC3/HLA-DMB/ } \\
\text { HLA-G/CALR/PSMA3/KLC1/HLA-DMA/PSMB4/PSMD4/TAP1/HLA-F/PSMD13/AP3D1/ } \\
\text { AP1S2/HLA-C/VAMP3/HLA-DPB1/PSME3/PSMB9/OSBPL1A/PSMB10 }\end{array}$ & $\mathrm{BP}$ \\
\hline GO:0002478 & $\begin{array}{l}\text { antigen processing } \\
\text { and presentation of } \\
\text { exogenous peptide } \\
\text { antigen }\end{array}$ & $2.89 \mathrm{E}-08$ & $\begin{array}{l}\text { HLA-DRA/DYNC1LI2/HLA-DQB1/HLA-B/PSMA7/HLA-DPA1/PSMB8/PSMC3/HLA-DMB/ } \\
\text { HLA-G/CALR/PSMA3/KLC1/HLA-DMA/PSMB4/PSMD4/TAP1/HLA-F/PSMD13/AP1S2/ } \\
\text { HLA-C/VAMP3/HLA-DPB1/PSME3/PSMB9/OSBPL1A/PSMB10 }\end{array}$ & $\mathrm{BP}$ \\
\hline GO:0005681 & spliceosomal complex & $1.85 \mathrm{E}-10$ & $\begin{array}{l}\text { LUC7L3/HNRNPF/RBM5/DHX15/HNRNPM/RBM25/HNRNPR/PRPF31/TRA2B/SRRM2/ } \\
\text { DDX39A/DDX41/WAC/LGALS3/HNRNPA2B1/PNN/PRPF4B/HNRNPC/SRRM1/SYNCRIP/ } \\
\text { SNRPB/IK/SF3B4/DHX35/SART1/RBM8A/LSM4/USP39/PRPF19/HNRNPA3 }\end{array}$ & $\mathrm{CC}$ \\
\hline GO:0042611 & MHC protein complex & 4.84E-07 & $\begin{array}{l}\text { HLA-DRA/HLA-DQB1/HLA-B/HLA-DPA1/HLA-DMB/HLA-G/HLA-DMA/HLA-F/HLA-C/ } \\
\text { HLA-DPB1 }\end{array}$ & $\mathrm{CC}$ \\
\hline GO:0005925 & focal adhesion & 4.84E-07 & $\begin{array}{l}\text { IQGAP1/FERMT2/CD99/FHL1/ACTB/HCK/PALLD/EZR/ZFYVE21/PDPK1/YWHAB/GDI/ } \\
\text { DLC1/ITGA8/CALR/ACTR3/KRAS/NRP1/ARPC1B/CAT/FLRT3/PTPRC/EFNB2/EPB41L5/ } \\
\text { PPFIBP1/EGFR/CAV1/DAB2/LAP3/HSP90B1/CAP1/P4HB/NFASC/PTK2/DST/RAC1/ } \\
\text { TSPAN4/SNTB2 }\end{array}$ & $\mathrm{CC}$ \\
\hline GO:0005924 & $\begin{array}{l}\text { cell-substrate adherens } \\
\text { junction }\end{array}$ & 4.84E-07 & $\begin{array}{l}\text { IQGAP1/FERMT2/CD99/FHL1/ACTB/HCK/PALLD/EZR/ZFYVE21/PDPK1/YWHAB/GDI2/ } \\
\text { DLC1/ITGA8/CALR/ACTR3/KRAS/NRP1/ARPC1B/CAT/FLRT3/PTPRC/EFNB2/EPB41L5/ } \\
\text { PPFIBP1/EGFR/CAV1/DAB2/LAP3/HSP90B1/CAP1/P4HB/NFASC/PTK2/DST/RAC1/ } \\
\text { TSPAN4/SNTB2 }\end{array}$ & $\mathrm{CC}$ \\
\hline GO:0030055 & cell-substrate junction & $5.47 \mathrm{E}-07$ & $\begin{array}{l}\text { IQGAP1/FERMT2/CD99/FHL1/ACTB/HCK/PALLD/EZR/ZFYVE21/PDPK1/YWHAB/GDI/ } \\
\text { DLC1/ITGA8/CALR/ACTR3/KRAS/NRP1/ARPC1B/CAT/FLRT3/PTPRC/EFNB2/EPB41L5/ } \\
\text { PPFIBP1/EGFR/CAV1/DAB2/LAP3/HSP90B1/CAP1/P4HB/NFASC/PTK2/DST/RAC1/ } \\
\text { TSPAN4/SNTB2 }\end{array}$ & $\mathrm{CC}$ \\
\hline
\end{tabular}




\begin{tabular}{|c|c|c|c|c|}
\hline ID & Description & Adj.P.Value & Gene ID & Category \\
\hline GO:0071013 & $\begin{array}{l}\text { catalytic step } 2 \\
\text { spliceosome }\end{array}$ & $1.38 \mathrm{E}-06$ & $\begin{array}{l}\text { HNRNPF/HNRNPM/HNRNPR/SRRM2/DDX41/HNRNPA2B1/PNN/PRPF4B/HNRNPC/ } \\
\text { SRRM1/SYNCRIP/SNRPB/DHX35/SART1/RBM8A/PRPF19/HNRNPA3 }\end{array}$ & $\mathrm{CC}$ \\
\hline GO:0030666 & $\begin{array}{l}\text { endocytic vesicle } \\
\text { membrane }\end{array}$ & $1.27 \mathrm{E}-05$ & $\begin{array}{l}\text { HLA-DRA/HLA-DQB1/HLA-B/HLA-DPA1/RAB31/CD163/PICALM/ATG12/HLA-G/CALR/ } \\
\text { TAP1/HLA-F/TYRP1/AP1S2/HLA-C/VAMP3/HLA-DPB1/EGFR/CAV1/GPR161/ATP6V0E2 }\end{array}$ & $\mathrm{CC}$ \\
\hline GO:0071556 & $\begin{array}{l}\text { integral component } \\
\text { of lumenal side of } \\
\text { endoplasmic reticulum } \\
\text { membrane }\end{array}$ & $1.27 \mathrm{E}-05$ & HLA-DRA/HLA-DQB1/HLA-B/HLA-DPA1/HLA-G/CALR/HLA-F/HLA-C/HLA-DPB1 & $\mathrm{CC}$ \\
\hline GO:0042605 & peptide antigen binding & 4.99E-06 & HLA-DRA/HLA-DQB1/HLA-B/HLA-DPA1/SLC7A8/HLA-G/TAP1/HLA-F/HLA-C/HLA-DPB1 & MF \\
\hline GO:0050839 & $\begin{array}{l}\text { cell adhesion molecule } \\
\text { binding }\end{array}$ & $6.24 \mathrm{E}-05$ & $\begin{array}{l}\text { IQGAP1/CALD1/RAN/COL3A1/FN1/EZR/SERBP1/RAB1A/PKN2/PICALM/LYN/KIF5B/ } \\
\text { IGF1/YWHAB/ICAM2/SNX1/HSP90AB1/SWAP70/MYO6/CALR/STAT1/LRRFIP1/COL4A3/ } \\
\text { NUDC/EPB41L1/EIF5/ZC3H15/EIF4G1/KTN1/ENO1/ITGB2/SNX2/PCMT1/PPFIBP1/EGFR/ } \\
\text { P4HB/DST/TSPAN4/CXADR }\end{array}$ & MF \\
\hline GO:0042277 & peptide binding & $6.24 \mathrm{E}-05$ & $\begin{array}{l}\text { HLA-DRA/HLA-DQB1/PPP3R1/HLA-B/HLA-DPA1/PPIG/NPEPPS/TNPO1/CRHBP/EDNRB/ } \\
\text { SLC7A8/KPNB1/HSP90AB1/CD14/HLA-G/TNPO3/CALR/KPNA2/TAP1/HLA-F/ITGB2/PPIC/ } \\
\text { HLA-C/HLA-DPB1/NKTR/PPARG/NPR3 }\end{array}$ & MF \\
\hline GO:0033218 & amide binding & $6.24 \mathrm{E}-05$ & $\begin{array}{l}\text { HLA-DRA/HLA-DQB1/PPP3R1/HLA-B/HLA-DPA1/PPIG/NPEPPS/TNPO1/CRHBP/EDNRB/ } \\
\text { SLC7A8/KPNB1/HSP90AB1/CD14/HLA-G/TNPO3/CALR/KPNA2/TAP1/HLA-F/ITGB2/ } \\
\text { FOLR1/PPIC/HLA-C/HLA-DPB1/NKTR/COL4A3BP/PPARG/NPR3 }\end{array}$ & MF \\
\hline GO:0045296 & cadherin binding & $9.40 \mathrm{E}-04$ & $\begin{array}{l}\text { IQGAP1/CALD1/RAN/EZR/SERBP1/RAB1A/PKN2/PICALM/KIF5B/YWHAB/SNX1/ } \\
\text { HSP90AB1/SWAP70/MYO6/STAT1/LRRFIP1/NUDC/EPB41L1/EIF5/ZC3H15/EIF4G1/KTN1/ } \\
\text { ENO1/SNX2/PCMT1/PPFIBP1/EGFR }\end{array}$ & MF \\
\hline GO:0003779 & actin binding & $3.00 \mathrm{E}-03$ & $\begin{array}{l}\text { CALD1/TPM1/MYH10/GBP1/TAGLN/MYLK/ENC1/PHACTR2/PALLD/EZR/LIMCH1/ } \\
\text { MYO6/CXCR4/HCLS1/ACTR3/EPB41L1/GMFG/GC/ADD3/ARPC1B/PLS1/YWHAH/EGFR/ } \\
\text { WDR1/KLHL20/CAP1/PTK2/DST/ARPC1A/COBL/SNTB2 }\end{array}$ & MF \\
\hline GO:0004298 & $\begin{array}{l}\text { threonine-type } \\
\text { endopeptidase activity }\end{array}$ & $5.19 \mathrm{E}-03$ & PSMA7/PSMB8/PSMA3/PSMB4/PSMB9/PSMB10 & MF \\
\hline GO:0070003 & $\begin{array}{l}\text { threonine-type peptidase } \\
\text { activity }\end{array}$ & $5.19 \mathrm{E}-03$ & PSMA7/PSMB8/PSMA3/PSMB4/PSMB9/PSMB10 & MF \\
\hline
\end{tabular}

\section{PPI Network Construction and Hub-Gene Screening}

The major part of the constructed PPI network is presented in Figure 3A. To further reduce the scope for analysis, we analyzed the PPI network by using the four analysis methods in CytoHubba based on the R package Venn diagram. We used the top ranked 20 DEGs to identify seven overlapping hub genes screened through the four CytoHubba methods (Degree, EPC, MCC, and DMNC) in cytoscape software (Figure 3B-F). The seven overlapping hub genes included FUS, DHX15, PRPF31, PQBP1, RBM5, HNRNPR, and TRA2B. Strikingly, the identified hub DEGs in our study have never been reported in literature related to FSGS. In addition, these genes simultaneously ranked to the high position by the four different CytoHubba methods suggests they may play important roles in the development of FSGS.

\section{Gene Expression Validation in In -Vitro Experiments}

We validated the 7 top ranked hub genes expression in the FSGS model in vitro (Figure 4). Quantitative real-time PCR indicated that the mRNA levels of FUS, DHX15, PQBP1, RBM5, and HNRNPR were up-regulated after they were stimulated by adriamycin (ADR). The changes in PRPF31 and TRA2B mRNA were statistically insignificant.
Except for PRPF31 and TRA2B, the changes in all of the other gene expression levels were consistent with the bioinformatic analysis results (Supplementary Table 1), with the accordance rate reaching $70 \%$ approximately.

\section{Extended information on Potential Hub Genes}

On the basis of the above results, we used the abbreviations of the seven hub genes and FSGS as keywords to search the NCBI database for identifying the potential relationship between these hub genes and FSGS. Search results revealed that the seven hub genes have never been reported in literature related to FSGS. Then, we carefully collated information relevant to the biological functions and signaling pathways that involve these hub genes on Gene Cards website (https:// www.genecards.org). The results indicate that heterogeneous nuclear ribonucleoprotein $\mathrm{F}$ (HNRNPF) is closely related to Nrf2 gene expression, renal angiotensinogen gene expression, the TGF- $\beta 1$ signaling pathway, and oxidative stress. Moreover, RNA-binding motif protein 5 (RBM5) is involved in apoptosis induction in many tumors. Ultimately, in accordance with the accepted pathogenesis of FSGS, we selected HNRNPF and RBM5 as representative targets for further discussion. Extended information on HNRNPF and RBM5 are shown in Table 4. 
A

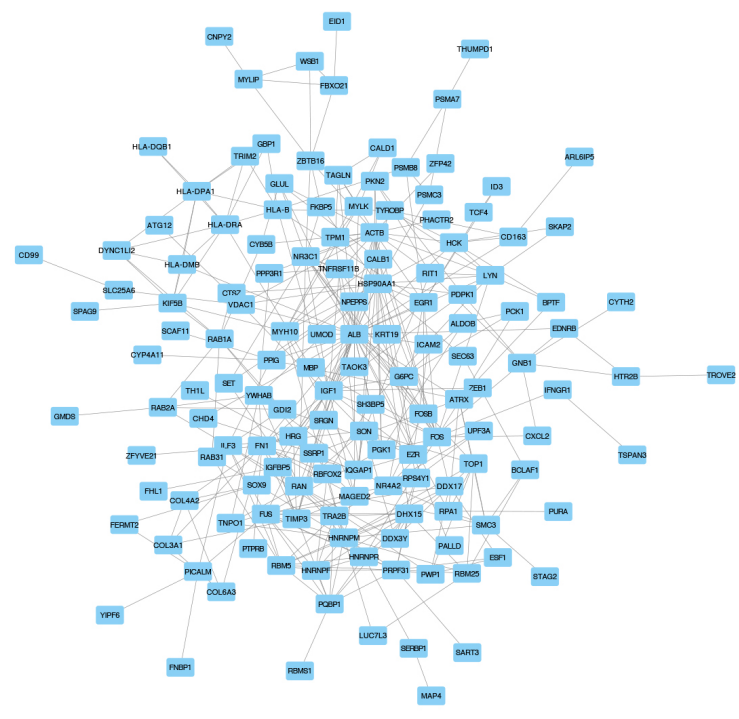

C

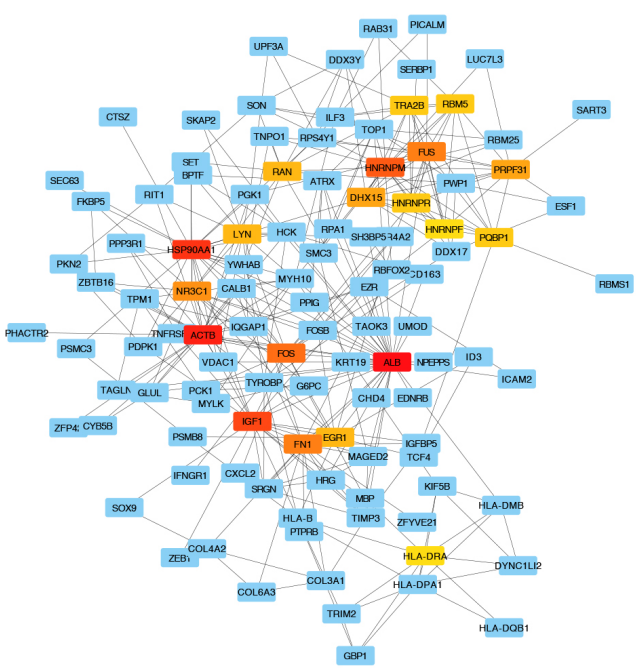

\section{E}

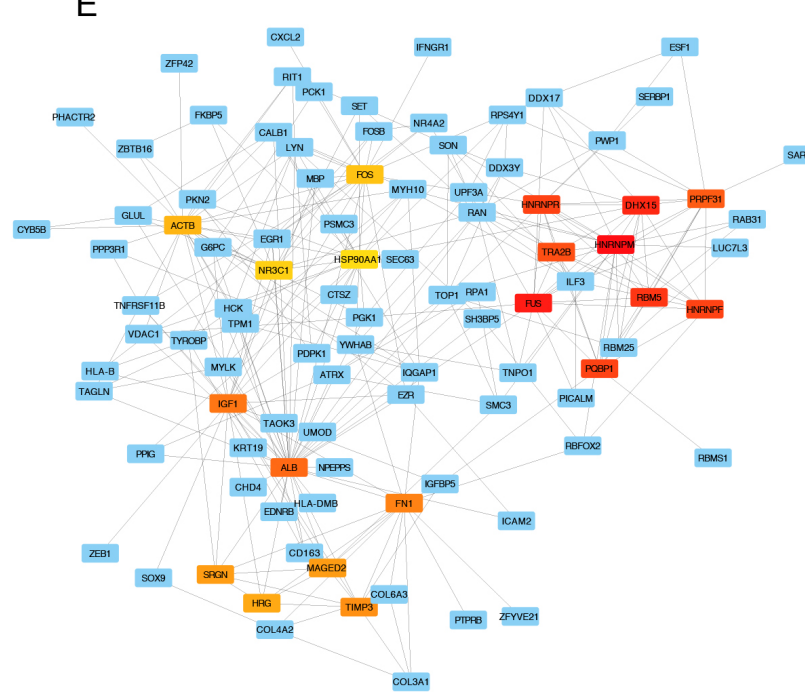

B

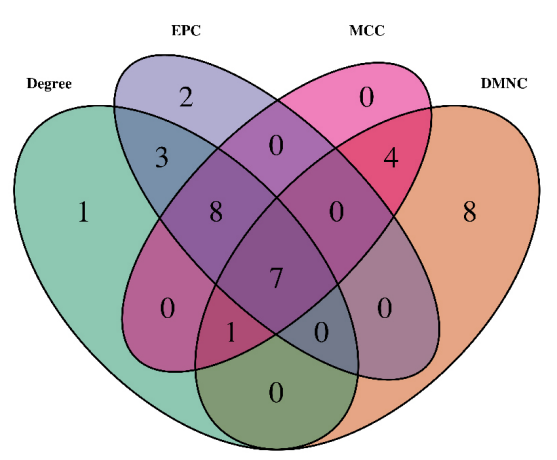

D

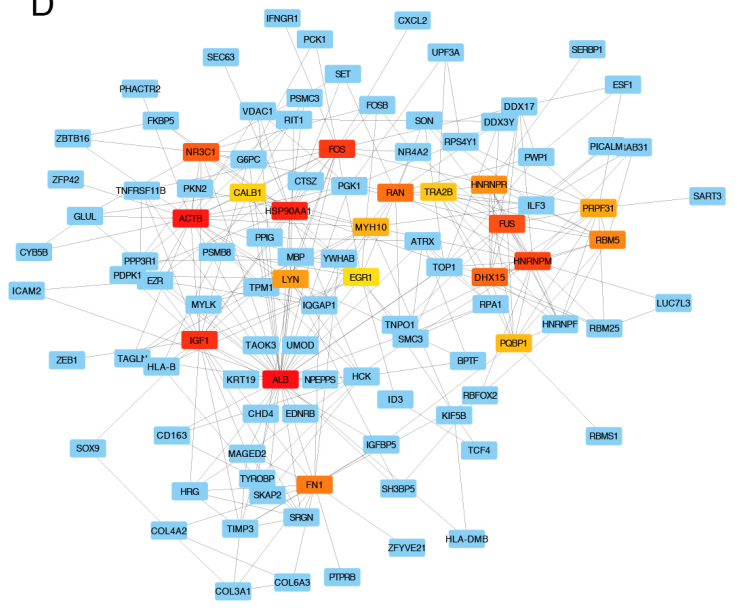

$\mathrm{F}$

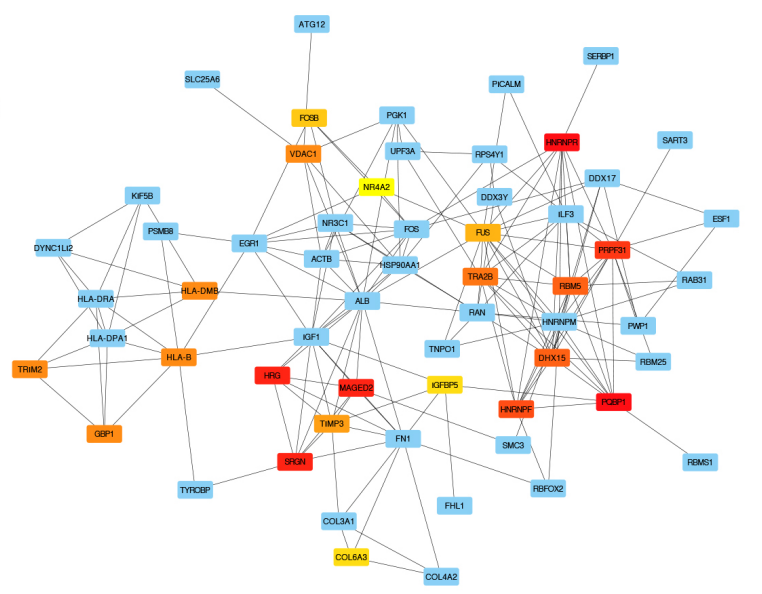

Figure 3: Protein-protein interaction (PPI) networks of DEGs and screening of hub genes

A: The major part of PPI network; B: Venn diagram of differentially expressed genes based on four screening methods including "Degree", "EPC", "MCC", and "DMNC"; C: PPI of DEGs screened by the method "Degree" in Cytohubba; D: PPI of DEGs screened by the method "EPC" in Cytohubba; E: PPI of DEGs screened by the method "MCC" in Cytohubba; F: PPI of DEGs screened by the method "DMNC" in Cytohubba. The depth of red represents the rank of the hub genes. 


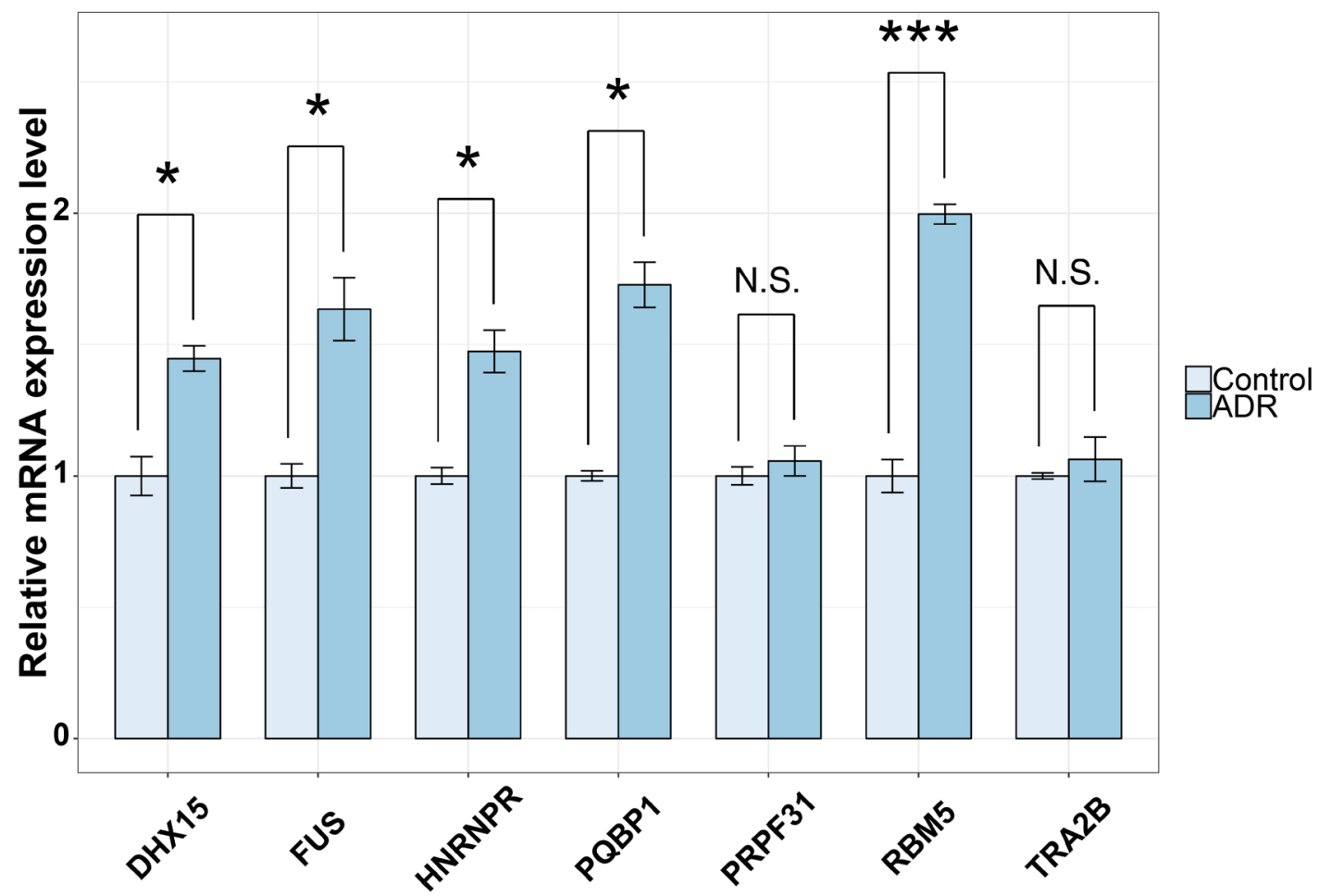

Figure 4. In vitro validation for the novel hub genes

Adriamycin (ADR) $(0.125 \mathrm{ug} / \mathrm{ml})$ was used to stimulate confluent conditionally immortalized human podocytes (LY893) for 0 (control) and $48 \mathrm{~h}$. The mRNA expression levels of 7 novel top hub genes were measured by quantitative real-time PCR. The mRNA expression levels of the target genes were normalized to that of GAPDH. The data in three separate experiments were presented as mean \pm SD $(n=3)$. *Significantly changed expression levels in ADR-stimulated cells compared with the controls $(\mathrm{P}<0.05)$. N.S., no significant difference $(\mathrm{P}>0.05)$

Table 4. Extended Information of The Potential MN-Related Hub Genes.

\begin{tabular}{|c|c|c|c|c|}
\hline Gene & Function & Disease/Cells & DOI & Authors \\
\hline \multirow[t]{7}{*}{ HNRNPF } & $\begin{array}{l}\text { Stimulates renal Ace- } 2 \text { gene expression and prevents TGF- } \\
\beta 1 \text {-induced kidney injury }\end{array}$ & Diabetes & $10.1007 / \mathrm{s} 00125-015-3700-\mathrm{y}$ & Lo CS, Shi Y, Chang SY \\
\hline & $\begin{array}{l}\text { Mediate renal angiotensinogen gene expression and } \\
\text { prevention of hypertension and kidney injury }\end{array}$ & Diabetes & $10.1007 / \mathrm{s} 00125-013-2910-4$ & Abdo S, Lo CS, Chenier I \\
\hline & Inhibits Nrf2 Gene Expression & Diabetic mice & 10.1210/en.2016-1576 & Ghosh A, Abdo S, Zhao S \\
\hline & Against oxidative stress & Diabetic mice & $10.2337 / \mathrm{db} 16-1588$ & Lo CS, Shi Y, Chenier \\
\hline & Suppresses angiotensinogen gene expression & Diabetic mice & $10.2337 / \mathrm{db} 11-1349$ & Lo CS, Chang SY, Chenier I \\
\hline & $\begin{array}{l}\text { Modulate the alternative splicing of the apoptotic mediator } \\
\text { Bcl-x }\end{array}$ & Human HeLa cells & 10.1074/jbc.M501070200 & GarneauD, Revil T, Fisette JF \\
\hline & Modulates angiotensinogen gene expression & Diabetes & 10.1681/ASN.2004080715 & Wei CC, Guo DF, Zhang SL \\
\hline \multirow[t]{6}{*}{ RBM5 } & $\begin{array}{l}\text { Inhibition of Wnt/ } \beta \text {-catenin signaling and induction of } \\
\text { apoptosis }\end{array}$ & Gliomas & $10.1186 / \mathrm{s} 12957-016-1084-1$ & Jiang Y, Sheng H, Meng L \\
\hline & Impacts cell proliferation and apoptosis & Lung cancer & $\begin{array}{l}\text { 10.1615/ } \\
\text { JEnvironPatholToxicolOncol.2017019366 }\end{array}$ & Prabhu VV, Devaraj N \\
\hline & Regulates the activity of $\mathrm{Wnt} / \beta$-catenin signaling & $\begin{array}{l}\text { Alveolar epithelial } \\
\text { injury }\end{array}$ & 10.3892/or.2015.3828 & Hao YQ, Su ZZ, Lv XJ \\
\hline & Promotes caspase activation & Human neuronal cells & $10.1038 / \mathrm{jcbfm} .2014 .242$ & $\begin{array}{l}\text { Jackson TC, Du L,Janesko- } \\
\text { Feldman K }\end{array}$ \\
\hline & Promotes neuronal apoptosis & Spinal cord injury & 10.1016/j.biocel.2014.12.020 & Zhang J, Cui Z, Feng G \\
\hline & Inhibits cell growth and induces apoptosis & Lung adenocarcinoma & $10.1186 / 1477-7819-10-160$ & Shao C, Zhao L, Wang K \\
\hline
\end{tabular}




\section{Discussion}

Bioinformatics is a newly developed interdisciplinary subject that combines biological science and computer science. Over the past few years, a growing body of research has used gene expression profiles to explore key genes in the pathogenesis of numerous diseases $[15,16,40,41]$. To our knowledge, our study is the first work that subjected FSGS to bioinformatic analysis. We identified 627 DEGs between the FSGS and control groups. These DEGs included numerous DEGs that have not been previously reported to be involved in FSGS. Then, we predicted DEG functions on the basis of GO annotations. The GO terms we identified included focal adhesion [31,32], cell adhesion molecule [33,34], cadherin [35], and actin binding [36]. These processes are associated with glomerulosclerosis. For example, the genetic deletion of Epb4115, a podocyte-specific focal adhesome component, results in podocyte detachment, severe proteinuria, and focal segmental glomerulosclerosis development [31]. In immortalized human podocytes, the overexpression of R431C mutant ANLN, an F-actin binding cell cycle gene, enhances podocyte motility [36]. Next, we identified seven overlapping hub genes by constructing PINs through four different analytical methods. Through an accurate search of the NCBI database, we identified HNRNPF and RBM5 as the representative targets for further elaboration.

HNRNPF is a protein-coding gene associated with gene expression. However, no research has been conducted on the role and mechanisms of HNRNPF in FSGS. In this work, we found that HNRNPF is an important DEG among the seven overlapping hub genes in the PPI networks. In addition, HNRNPF is deeply involved with Nrf2 [42], a renal angiotensinogen gene that is expressed in the kidney [43]. Furthermore, in diabetic mice, HNRNPF participates in the TGF- $\beta 1$ signaling pathway [44] and oxidative stress [45]. These genes and pathways have been confirmed to play vital roles in the pathogenesis of FSGS $[4,11,46]$. One research suggested that osthole could improve FSGS by activating the Nrf2 antioxidant pathway [47]. TGF- $\beta 1$ reduces WT1 expression in mouse podocytes and cultured human podocytes before overt glomerulosclerosis begins [46]. In addition, damage to podocytes stimulates TGF- $\beta 1$ and TGF- $\beta$ IIR expression in glomerular epithelial cells; this effect eventually leads to extracellular matrix overproduction [48]. On the basis of our analytical results, we conclude that HNRNPF likely participates in FSGS through oxidative stress-associated genes and pathways and is a potential biomarker for this disease.

RBM5 is a nuclear RNA-binding protein that is often genetically deleted in renal cancer ${ }^{49}$. Unfortunately, the role of RBM5 in FSGS remains unreported. In our study, we identified RBM5 as an upregulated hub gene in FSGS. Moreover, RBM5 actively participates in apoptosis induction in tumors $[50,51]$. Apoptosis-induced podocyte damage is a key factor in the pathogenesis of FSGS [12,52]. On the basis of previous findings combined with our present bioinformatic analysis results, we speculate that RBM5 may participate in apoptosis promotion during FSGS progression.

\section{Conclusion}

Our study provides a fast, powerful, and effective strategy for the discovery of novel diagnostic biomarkers and therapeutic targets for
FSGS. Our results suggest that HNRNPF and RBM5 are molecular candidates for the diagnosis and treatment of FSGS. However, our results are preliminary, and further work is needed to decipher these candidate genes.

\section{Author contributions}

Q.M and Z.H designed the research; Z.H analyzed the data and performed the research; D.Z wrote the manuscript. All authors read and approved the final manuscript.

Qianhong Ma and Dongmei Zhang contributed equally to this work and should be considered co-first authors.

\section{Funding}

This work was supported by grants from the National Natural Science Foundation of China (Grant No. 81200453).

\section{References}

1. Pollak MR (2008) Focal segmental glomerulosclerosis: recent advancesyper. Curr Opin Nephrol H tens 17: 138-142.

2. Wiggins RC (2007) The spectrum of podocytopathies: a unifying view of glomerular diseases. Kidney Int 71: 1205-1214.

3. Kriz W, Lemley KV (2015) A potential role for mechanical forces in the detachment of podocytes and the progression of CKD. J Am Soc Nephrol 26: 258-269.

4. Lin EY, Bayarsengee U, Wang CC, Chiang YH, Cheng CW (2018) The natural compound 2,3,5,4'-tetrahydroxystilbene-2-O-beta-d glucoside protects against adriamycin-induced nephropathy through activating the Nrf2-Keap1 antioxidant pathway. Environ Toxicol 33: 72-82.

5. Raij L, Tian R, Wong JS, He JC, Campbell KN, et al. (2016) Podocyte injury: the role of proteinuria, urinary plasminogen, and oxidative stress. Am J Physiol Renal Physiol 311: 1308-1317.

6. Yang SM, Ka SM, Hua KF, Wu TF, Chuang YP, et al. (2013) Antroquinonol mitigates an accelerated and progressive IgA nephropathy model in mice by activating the Nrf2 pathway and inhibiting T cells and NLRP3 inflammasome. Free Radic Biol Med 61: 285-297.

7. Oh CJ, Kim JY, Choi YK, Lee IK, Kim HJ, et al. (2012) Dimethylfumarate attenuates renal fibrosis via NF-E2-related factor 2-mediated inhibition of transforming growth factor-beta/Smad signaling. PloS one 7: 45870.

8. Tsai PY, Ka SM, Chao TK, Chang JM, Lin SH, et al. (2011) Antroquinonol reduces oxidative stress by enhancing the Nrf2 signaling pathway and inhibits inflammation and sclerosis in focal segmental glomerulosclerosis mice. Free Radic Biol Med 50: 1503-1516.

9. Schiffer M, Bitzer M, Roberts IS, Kopp JB, Mundel P, et al. (2001) Apoptosis in podocytes induced by TGF-beta and Smad7. J Clin Invest 108: 807-816.

10. Schachter AD, Strehlau J, Zurakowski D, Kim YS, Strom TB, et al. (2000) Increased nuclear factor-kappaB and angiotensinogen gene expression in posttransplant recurrent focal segmental glomerulosclerosis. Transplantation 70: 1107-1110.

11. Luther Y, Bantis C, Ivens K, Fehsel K, Kolb-Bachhofen V, et al. (2003) Effects of the genetic polymorphisms of the renin-angiotensin system on focal segmental glomerulosclerosis. Kidney Blood Press Res 26: 333-337.

12. Liu L, Lin W, Zhang Q, Cao W, Liu Z (2016) TGF-beta induces miR-30d down-regulation and podocyte injury through Smad2/3 and HDAC3-associated transcriptional repression. J Mol Med (Berl) 94: 291-300.

13. Xue Y, Yin P, Li G, Zhong D (2018) Genome-wide Integration Study of Circulating miRNAs and Peripheral Whole-Blood mRNAs of Male Acute Ischemic Stroke Patients. Neuroscience 380: 27-37.

14. Li H, Zhen Y, Geng Y, Feng J, Wang J (2018) Exploring the Molecular Mechanism of Thoracic Aortic Aneurysm via Bioinformatics Analysis. Med Sci Monit 24: $1533-1539$.

15. Dong B, Wang G, Yao J, Yuan P, Kang W, et al. (2017) Predicting novel genes and pathways associated with osteosarcoma by using bioinformatics analysis. Gene 628: 32-37.

16. Luo Y, Zhang C, Tang F, Zhao J, Shen C, et al. (2015) Bioinformatics identification of potentially involved microRNAs in Tibetan with gastric cancer based on microRNA profiling. Cancer Cell Int 15: 115.

17. Wang JP, Leng JY, Zhang RK, Zhang L, Zang B, et al. (2018) Functional analysis of gene expression profiling-based prediction in bladder cancer. Oncol Lett 15: $8417-8423$. 
18. Dai J, Ma Y, Chu S, Le N, Cao J, et al. (2018) Identification of key genes and pathways in meningioma by bioinformatics analysis. Oncol Lett 15: 8245-8252.

19. Lin P, Wen DY, Dang YW, He Y, Yang H, et al. (2018) Comprehensive and Integrative Analysis Reveals the Diagnostic, Clinicopathological and Prognostic Significance of Polo-Like Kinase 1 in Hepatocellular Carcinoma. Cell Physiol Biochem 47: 925-947.

20. Yao T, Wang Q, Zhang W, Bian A, Zhang J (2016) Identification of genes associated with renal cell carcinoma using gene expression profiling analysis. Oncol Lett 12: 73-78.

21. Shu B, Fang Y, He W, Yang J, Dai C (2018) Identification of macrophage-related candidate genes in lupus nephritis using bioinformatics analysis. Cell Signal 46: $43-51$.

22. Cui Y, Liu S, Cui W, Gao D, Zhou W, et al. (2017) Identification of potential biomarkers and therapeutic targets for human IgA nephropathy and hypertensive nephropathy by bioinformatics analysis. Molecular medicine reports 16: $3087-$ 3094.

23. Zhou LT, Qiu S, Lv LL, Li ZL, Liu H, et al. (2018) Integrative Bioinformatics Analysis Provides Insight into the Molecular Mechanisms of Chronic Kidney Disease. Kidney Blood Press Res 43: 568-581.

24. Gautier L, Cope L, Bolstad BM, Irizarry RA (2004) affy--analysis of Affymetrix GeneChip data at the probe level. Bioinformatics 20: 307-315.

25. Ritchie ME, Phipson B, Wu D, Hu Y, Shi, et al. (2015) limma powers differential expression analyses for RNA-sequencing and microarray studies. Nucleic Acids Res 43: 47.

26. Yu G, Wang LG, Han Y, He QY (2012) Cluster Profiler: an R package for comparing biological themes among gene clusters. OMICS 16: 284-287.

27. Chin CH, Chen SH, Wu HH, Ho CW, Ko MT, et al. (2014) cytoHubba: identifying hub objects and sub-networks from complex interactome. BMC Syst Biol 8: 11

28. Chen H, Boutros PC (2011) VennDiagram: a package for the generation of highlycustomizable Venn and Euler diagrams in R. BMC Bioinformatics 12: 35.

29. Shannon P, Markiel A, Ozier O, Wang JT, Amin N, et al. (2003) Cytoscape: a software environment for integrated models of biomolecular interaction networks. Genome Res 13: 2498-2504.

30. Kachurina N, Chung CF, Benderoff E, Babayeva S, Bitzan M, et al. (2016) Novel unbiased assay for circulating podocyte-toxic factors associated with recurrent focal segmental glomerulosclerosis. Am J Physiol Renal Physiol 310: 1148-1156.

31. Schell C, Rogg M, Suhm M, Helmstadter M, Sellung D, et al. (2017) The FERM protein EPB41L5 regulates actomyosin contractility and focal adhesion formation to maintain the kidney filtration barrier. Proc Natl Acad Sci U S A 114: 4621-4630.

32. Sever S, Schiffer M (2018) Actin dynamics at focal adhesions: a common endpoint and putative therapeutic target for proteinuric kidney diseases. Kidney Int 93: 1298-1307

33. Gong W, Chen C, Xiong F, Yang Z, Wang Y, et al. (2016) CKIP-1 ameliorates high glucose-induced expression of fibronectin and intercellular cell adhesion molecule- 1 by activating the Nrf2/ARE pathway in glomerular mesangial cells. Biochem Pharmacol 116: 140-152.

34. Huang J, Filipe A, Rahuel C, Bonnin P, Mesnard L, et al. ( 2014) Lutheran/basal cell adhesion molecule accelerates progression of crescentic glomerulonephritis in mice. Kidney Int 85: 1123-1136.

35. Naves MA, Requiao-Moura LR, Soares MF, Silva-Junior JA, Mastroianni-Kirsztajn G, et al. (2012) Podocyte Wnt/ss-catenin pathway is activated by integrin-linked kinase in clinical and experimental focal segmental glomerulosclerosis. Journal of nephrology 25: 401-409.
36. Gbadegesin RA, Hall G, Adeyemo A, Hanke N, Tossidou I, et al. (2014) Mutations in the gene that encodes the F-actin binding protein anillin cause FSGS. Journal of the American Society of Nephrology: JASN 25: 1991-2002.

37. Papazachariou L, Papagregoriou G, Hadjipanagi D, Dwmosthenous P, Voskarides $\mathrm{K}$, et al. (2017) Frequent COL4 mutations in familial microhematuria accompanied by later-onset Alport nephropathy due to focal segmental glomerulosclerosis. Clin Genet 92: 517-527.

38. Johnstone DB, Zhang J, George B, Leon C, Gachet C, et al. (2011) Podocytespecific deletion of Myh9 encoding nonmuscle myosin heavy chain 2A predisposes mice to glomerulopathy. Mol Cell Biol 31: 2162-2170.

39. Boyer O, Benoit G, Gribouval O, Nevo F, Tete MJ, et al. (2011) Mutations in INF2 are a major cause of autosomal dominant focal segmental glomerulosclerosis. $\mathrm{J} \mathrm{Am}$ Soc Nephrol 22: 239-245.

40. Li WX, He K, Tang L, Dai SX, Li GH, et al. (2017) Comprehensive tissue-specific gene set enrichment analysis and transcription factor analysis of breast cancer by integrating 14 gene expression datasets. Oncotarget 8: 6775-6786.

41. Cui H, Zhang Y, Zhang Q, Chen W, Zhao H, et al. (2017) A comprehensive genome-wide analysis of long noncoding RNA expression profile in hepatocellular carcinoma. Cancer Med 6: 2932-2941.

42. Ghosh A, Abdo S, Zhao S, Wu CH, Shi Y, et al. (2017) Insulin Inhibits Nrf2 Gene Expression via Heterogeneous Nuclear Ribonucleoprotein F/K in Diabetic Mice. Endocrinology 158: 903-919.

43. Wei CC, Guo DF, Zhang SL, Ingelfinger JR, Chan JS (2005) Heterogenous nuclear ribonucleoprotein $\mathrm{F}$ modulates angiotensinogen gene expression in rat kidney proximal tubular cells. J Am Soc Nephrol 16: 616-628.

44. Lo CS, Shi Y, Chang SY, Abdo S, Chenier I, et al. (2015) Overexpression of heterogeneous nuclear ribonucleoprotein $\mathrm{F}$ stimulates renal Ace-2 gene expression and prevents TGF-beta1-induced kidney injury in a mouse model of diabetes. Diabetologia 58: 2443-2454.

45. Lo CS, Shi Y, Chenier I, Ghosh A, Wu CH, et al. (2017) Heterogeneous Nuclear Ribonucleoprotein F Stimulates Sirtuin-1 Gene Expression and Attenuates Nephropathy Progression in Diabetic Mice. Diabetes 66: 1964-1978.

46. Sakairi T, Abe Y, Kopp JB (2011) TGF-betal reduces Wilms' tumor suppressor gene expression in podocytes. Nephrol Dial Transplant 26: 2746-2752.

47. Yang SM, Chan YL, Hua KF, Chang JM, Chen HL, et al. (2014) Osthole improves an accelerated focal segmental glomerulosclerosis model in the early stage by activating the Nrf2 antioxidant pathway and subsequently inhibiting NF-kappaBmediated COX-2 expression and apoptosis. Free Radic Biol Med 73: 260-269.

48. Kim JH, Kim BK, Moon KC, Hong HK, Lee HS (2003) Activation of the TGFbeta/Smad signaling pathway in focal segmental glomerulosclerosis. Kidney Int 64 : 1715-1721.

49. Bechara EG, Sebestyen E, Bernardis I, Eyras E, Valcarcel J (2013) RBM5, 6 , and 10 differentially regulate NUMB alternative splicing to control cancer cell proliferation. Mol Cell 52: 720-733.

50. Jiang Y, Sheng H, Meng L, Yue H, Li B, et al. (2017) RBM5 inhibits tumorigenesis of gliomas through inhibition of Wnt/beta-catenin signaling and induction of apoptosis. World J Surg Oncol 15: 9.

51. Prabhu VV, Devaraj N (2017) Regulating RNA Binding Motif 5 Gene ExpressionA Novel Therapeutic Target for Lung Cancer. J Environ Pathol Toxicol Oncol 36: 99-105.

52. Nafar M, Kalantari S, Samavat S, Rezaei-Tavirani M, Rutishuser D, et al. (2014) The novel diagnostic biomarkers for focal segmental glomerulosclerosis. Int $J$ Nephrol 2014: 574261.

Citation:

Qianhong Ma, Zhang D, Huang Z (2019) Novel Pathology-Related Hub Genes in Focal Segmental Glomerulosclerosis. J Clin Res Med Volume 2 (5): 1-10. 
Supplementary Table 1

\begin{tabular}{|c|c|c|c|c|c|c|}
\hline gene.symbols & $\log F C$ & AveExpr & ts & P.Value & adj.P.Val & B \\
\hline RPS4Y1 & 2.569009422 & 9.570289361 & 3.101358611 & 0.004371381 & 0.011115768 & -2.711721859 \\
\hline PLPP3 & 2.485089122 & 9.251833831 & 7.62668606 & $2.66 \mathrm{E}-08$ & 7.13E-07 & 9.068379301 \\
\hline DDX3Y & 2.478844353 & 7.003027727 & 2.920309189 & 0.006843408 & 0.016208722 & -3.132862184 \\
\hline SART3 & 2.470577198 & 7.660356798 & 12.25209245 & $9.40 \mathrm{E}-13$ & $5.82 \mathrm{E}-10$ & 19.16340462 \\
\hline TCF4 & 2.418989646 & 7.335132517 & 11.59356528 & $3.44 \mathrm{E}-12$ & $1.27 \mathrm{E}-09$ & 17.89787797 \\
\hline CYP4A11 & -2.412274749 & 9.12866545 & -6.123580669 & $1.33 \mathrm{E}-06$ & 1.42E-05 & 5.192258061 \\
\hline FOSB & -2.356258176 & 8.074381933 & -7.877904555 & $1.42 \mathrm{E}-08$ & 4.53E-07 & 9.690625188 \\
\hline TROVE2 & 2.355365338 & 9.457713493 & 7.605950945 & $2.80 \mathrm{E}-08$ & 7.39E-07 & 9.016659035 \\
\hline IQGAP1 & 2.290645788 & 8.14538406 & 9.69432624 & $1.94 \mathrm{E}-10$ & $2.19 \mathrm{E}-08$ & 13.93671972 \\
\hline MBP & 2.255967535 & 7.587944516 & 12.62989302 & 4.56E-13 & $3.91 \mathrm{E}-10$ & 19.86587003 \\
\hline CALD1 & 2.192562666 & 8.074505734 & 11.18804096 & $7.85 \mathrm{E}-12$ & 2.21E-09 & 17.09171526 \\
\hline EGR1 & -2.182777112 & 10.2801361 & -8.747798502 & $1.72 \mathrm{E}-09$ & $1.01 \mathrm{E}-07$ & 11.78050827 \\
\hline RBFOX2 & 2.164462681 & 8.69816763 & 10.33705244 & $4.72 \mathrm{E}-11$ & $8.22 \mathrm{E}-09$ & 15.33081151 \\
\hline IGFBP5 & 2.148130254 & 9.995294632 & 5.537086859 & $6.45 \mathrm{E}-06$ & 5.09E-05 & 3.626766637 \\
\hline CDC42BPA & 2.079395261 & 9.770721553 & 7.925115034 & $1.26 \mathrm{E}-08$ & 4.20E-07 & 9.806647308 \\
\hline SMAD1 & 2.076607382 & 7.949965987 & 8.465377555 & 3.38E-09 & $1.61 \mathrm{E}-07$ & 11.11324049 \\
\hline G6PC & -2.074536589 & 6.566342687 & -4.459033616 & 0.000121983 & 0.000557225 & 0.736400459 \\
\hline ALB & -2.073497949 & 9.571928342 & -4.114808392 & 0.000309678 & 0.001209773 & -0.171567409 \\
\hline ZEB1 & 2.066318697 & 8.614493251 & 10.45925661 & 3.63E-11 & 7.03E-09 & 15.5895635 \\
\hline TPM1 & 2.060897076 & 9.232448331 & 10.04753441 & $8.88 \mathrm{E}-11$ & $1.30 \mathrm{E}-08$ & 14.70977983 \\
\hline FERMT2 & 2.05930113 & 7.350506265 & 7.771402732 & $1.85 \mathrm{E}-08$ & $5.49 \mathrm{E}-07$ & 9.427823748 \\
\hline LUC7L3 & 2.047718235 & 8.759118544 & 8.718232863 & $1.85 \mathrm{E}-09$ & $1.06 \mathrm{E}-07$ & 11.71116708 \\
\hline RAN & 2.025548667 & 10.29196832 & 11.46235083 & 4.49E-12 & $1.47 \mathrm{E}-09$ & 17.63930778 \\
\hline SLC25A36 & 2.003665861 & 8.269066322 & 8.586494779 & $2.53 \mathrm{E}-09$ & $1.31 \mathrm{E}-07$ & 11.40073865 \\
\hline HLA-DRA & 1.992802428 & 11.12961293 & 7.574703865 & 3.03E-08 & 7.84E-07 & 8.938615772 \\
\hline HTR2B & 1.980142562 & 6.49870054 & 5.606952454 & $5.34 \mathrm{E}-06$ & 4.35E-05 & 3.814138409 \\
\hline PCYOX1 & 1.966411418 & 7.433879894 & 7.068593108 & $1.10 \mathrm{E}-07$ & 2.03E-06 & 7.65787493 \\
\hline ATRX & 1.961414528 & 6.588331245 & 11.16381872 & $8.25 \mathrm{E}-12$ & 2.27E-09 & 17.04289981 \\
\hline DYNC1LI2 & 1.955508721 & 9.605304116 & 10.85559765 & $1.57 \mathrm{E}-11$ & 3.64E-09 & 16.41511633 \\
\hline CD99 & 1.9554319 & 9.927197771 & 8.57318363 & $2.61 \mathrm{E}-09$ & $1.33 \mathrm{E}-07$ & 11.36923982 \\
\hline CHD4 & 1.94490416 & 8.814477542 & 16.59170115 & $5.35 \mathrm{E}-16$ & $9.51 \mathrm{E}-12$ & 26.31762235 \\
\hline MYLIP & 1.938154662 & 9.419703765 & 7.548038454 & $3.24 \mathrm{E}-08$ & 8.23E-07 & 8.871918527 \\
\hline HNRNPF & 1.934376435 & 8.42993207 & 13.0216741 & $2.19 \mathrm{E}-13$ & 2.32E-10 & 20.57678872 \\
\hline HLA-DQB1 & 1.933559554 & 9.283173095 & 6.877515473 & $1.81 \mathrm{E}-07$ & 2.96E-06 & 7.16657257 \\
\hline FHL1 & 1.916965148 & 7.704294928 & 10.06888924 & $8.47 \mathrm{E}-11$ & $1.27 \mathrm{E}-08$ & 14.75597408 \\
\hline CTSZ & -1.912814074 & 8.256096924 & -9.422794947 & $3.59 \mathrm{E}-10$ & 3.49E-08 & 13.3308037 \\
\hline DDX17 & 1.900816911 & 7.156016292 & 6.849768897 & $1.94 \mathrm{E}-07$ & $3.11 \mathrm{E}-06$ & 7.094896981 \\
\hline THUMPD1 & 1.891011353 & 7.141971356 & 13.73428793 & $6.01 \mathrm{E}-14$ & 1.12E-10 & 21.82576576 \\
\hline PPP3R1 & -1.881530742 & 7.627366273 & -7.148865697 & $8.96 \mathrm{E}-08$ & $1.74 \mathrm{E}-06$ & 7.863044486 \\
\hline TNFRSF11B & 1.87836792 & 7.853323079 & 7.02736233 & $1.23 \mathrm{E}-07$ & $2.20 \mathrm{E}-06$ & 7.552206366 \\
\hline XIST & -1.863860797 & 7.615665673 & -2.956875261 & 0.006256155 & 0.015025427 & -3.048847061 \\
\hline SON & 1.851258175 & 7.997946847 & 8.840334385 & $1.39 \mathrm{E}-09$ & $8.53 \mathrm{E}-08$ & 11.99675806 \\
\hline
\end{tabular}


Huang Z (2019) Novel Pathology-Related Hub Genes in Focal Segmental Glomerulosclerosis

\begin{tabular}{|c|c|c|c|c|c|c|}
\hline gene.symbols & $\log F C$ & AveExpr & ts & P.Value & adj.P.Val & B \\
\hline GLUL & 1.846739708 & 7.937765075 & 9.235752198 & $5.51 \mathrm{E}-10$ & 4.67E-08 & 12.90751377 \\
\hline DKK3 & 1.838529383 & 7.235094143 & 6.88002716 & $1.80 \mathrm{E}-07$ & $2.95 \mathrm{E}-06$ & 7.173056725 \\
\hline BTG1 & 1.820054032 & 7.907833291 & 11.00485807 & $1.15 \mathrm{E}-11$ & 2.94E-09 & 16.72066783 \\
\hline TRIB2 & 1.81921404 & 8.182950746 & 8.768912824 & $1.64 \mathrm{E}-09$ & $9.74 \mathrm{E}-08$ & 11.82995473 \\
\hline RBM5 & 1.808667325 & 8.306181873 & 13.85226391 & $4.87 \mathrm{E}-14$ & $1.09 \mathrm{E}-10$ & 22.02721576 \\
\hline HLA-B & 1.803285216 & 12.34984324 & 6.340923899 & 7.42E-07 & 8.94E-06 & 5.766672368 \\
\hline MYH10 & 1.802983311 & 6.632652763 & 13.31027341 & $1.29 \mathrm{E}-13$ & $1.80 \mathrm{E}-10$ & 21.08934934 \\
\hline STAG2 & 1.793115173 & 5.860191501 & 13.76494033 & $5.69 \mathrm{E}-14$ & $1.12 \mathrm{E}-10$ & 21.87824888 \\
\hline GBP1 & 1.783205635 & 6.97780633 & 8.494851598 & $3.15 \mathrm{E}-09$ & $1.53 \mathrm{E}-07$ & 11.18338801 \\
\hline RPA1 & 1.779726763 & 9.056001662 & 9.084532378 & $7.82 \mathrm{E}-10$ & $5.91 \mathrm{E}-08$ & 12.56176241 \\
\hline BPTF & 1.776426474 & 7.907083176 & 7.356751223 & $5.27 \mathrm{E}-08$ & $1.17 \mathrm{E}-06$ & 8.390867161 \\
\hline PCK1 & -1.772301574 & 10.99438749 & -4.775458625 & $5.15 \mathrm{E}-05$ & 0.000272763 & 1.580947098 \\
\hline BTN3A3 & 1.772184439 & 6.173764331 & 8.425121851 & $3.73 \mathrm{E}-09$ & $1.74 \mathrm{E}-07$ & 11.01724161 \\
\hline TAGLN & 1.764332395 & 9.007016683 & 5.779780851 & $3.34 \mathrm{E}-06$ & $3.00 \mathrm{E}-05$ & 4.276795382 \\
\hline PSMA7 & 1.763068956 & 6.889044422 & 11.69687487 & $2.80 \mathrm{E}-12$ & $1.22 \mathrm{E}-09$ & 18.09994223 \\
\hline HLA-DPA1 & 1.762375082 & 10.82315093 & 6.098738113 & $1.42 \mathrm{E}-06$ & $1.50 \mathrm{E}-05$ & 5.126369472 \\
\hline MYLK & 1.75861114 & 10.39524956 & 6.152944852 & $1.23 \mathrm{E}-06$ & $1.34 \mathrm{E}-05$ & 5.270080435 \\
\hline YIPF6 & 1.747988074 & 9.294461389 & 8.337256865 & 4.61E-09 & 2.03E-07 & 10.80694239 \\
\hline COL3A1 & 1.741079028 & 10.03488916 & 6.880350494 & $1.80 \mathrm{E}-07$ & $2.95 \mathrm{E}-06$ & 7.173891393 \\
\hline ACTB & 1.739818254 & 10.62946301 & 4.630671948 & 7.64E-05 & 0.000379292 & 1.193646749 \\
\hline DHX15 & 1.737775319 & 10.02003843 & 9.85519139 & $1.36 \mathrm{E}-10$ & $1.72 \mathrm{E}-08$ & 14.29091385 \\
\hline PPIG & 1.731145889 & 7.407036172 & 7.251707604 & $6.89 \mathrm{E}-08$ & $1.43 \mathrm{E}-06$ & 8.124803038 \\
\hline SCAF11 & 1.721893208 & 9.371324456 & 10.2275776 & $5.99 \mathrm{E}-11$ & $9.60 \mathrm{E}-09$ & 15.09731143 \\
\hline HPGD & -1.717401682 & 10.07266901 & -6.740627536 & $2.59 \mathrm{E}-07$ & $3.87 \mathrm{E}-06$ & 6.812168581 \\
\hline DPP8 & 1.715249149 & 9.638588643 & 8.318534824 & 4.82E-09 & 2.09E-07 & 10.76199707 \\
\hline WSB1 & 1.714938423 & 8.596432117 & 6.91877743 & $1.62 \mathrm{E}-07$ & $2.75 \mathrm{E}-06$ & 7.273007517 \\
\hline ENC1 & 1.714016384 & 6.351234133 & 9.286980973 & $4.90 \mathrm{E}-10$ & 4.30E-08 & 13.02392792 \\
\hline FN1 & 1.713084538 & 9.852710944 & 6.048869862 & $1.62 \mathrm{E}-06$ & $1.68 \mathrm{E}-05$ & 4.993973035 \\
\hline UPF3A & 1.706676789 & 8.950115438 & 11.59802708 & $3.41 \mathrm{E}-12$ & $1.27 \mathrm{E}-09$ & 17.90663237 \\
\hline KRT19 & 1.703164941 & 8.133804492 & 4.840602977 & $4.31 \mathrm{E}-05$ & 0.000235133 & 1.755562232 \\
\hline BCLAF1 & 1.697469525 & 8.139217001 & 9.830297038 & $1.44 \mathrm{E}-10$ & $1.80 \mathrm{E}-08$ & 14.23633277 \\
\hline FBXO21 & 1.697287783 & 9.28818289 & 5.462538041 & $7.90 \mathrm{E}-06$ & 5.94E-05 & 3.426663378 \\
\hline IFNGR1 & 1.695558168 & 9.158556204 & 8.094628782 & 8.32E-09 & $3.11 \mathrm{E}-07$ & 10.22081389 \\
\hline HCK & 1.695111511 & 7.690905947 & 7.857688804 & $1.49 \mathrm{E}-08$ & 4.67E-07 & 9.640854784 \\
\hline CXCL2 & -1.686811585 & 6.477878156 & -4.50798237 & 0.000106777 & 0.000500487 & 0.866554554 \\
\hline PHACTR2 & 1.679845963 & 7.782456361 & 7.807529456 & $1.69 \mathrm{E}-08$ & $5.14 \mathrm{E}-07$ & 9.517134367 \\
\hline HNRNPM & 1.673764753 & 11.0821542 & 11.69753948 & $2.80 \mathrm{E}-12$ & $1.22 \mathrm{E}-09$ & 18.10123784 \\
\hline CAMK2N1 & -1.651602298 & 10.19208306 & -6.765897326 & $2.42 \mathrm{E}-07$ & $3.70 \mathrm{E}-06$ & 6.877740372 \\
\hline FUS & 1.650968802 & 9.619854977 & 13.27029455 & $1.39 \mathrm{E}-13$ & $1.82 \mathrm{E}-10$ & 21.01889984 \\
\hline PLPBP & 1.650135185 & 5.59234436 & 12.81694912 & $3.21 \mathrm{E}-13$ & $2.98 \mathrm{E}-10$ & 20.20749556 \\
\hline PSMB8 & 1.646543823 & 10.456135 & 7.886039857 & $1.39 \mathrm{E}-08$ & $4.48 \mathrm{E}-07$ & 9.71063892 \\
\hline SEC63 & 1.640469887 & 7.954060099 & 6.382735607 & $6.64 \mathrm{E}-07$ & $8.19 \mathrm{E}-06$ & 5.876729688 \\
\hline PALLD & 1.635448714 & 8.943061698 & 7.556440719 & $3.17 \mathrm{E}-08$ & 8.09E-07 & 8.892944454 \\
\hline
\end{tabular}


Huang Z (2019) Novel Pathology-Related Hub Genes in Focal Segmental Glomerulosclerosis

\begin{tabular}{|c|c|c|c|c|c|c|}
\hline gene.symbols & $\log F C$ & AveExpr & ts & P.Value & adj.P.Val & B \\
\hline ZBTB16 & 1.635125895 & 7.66230392 & 3.653696968 & 0.001057166 & 0.003348994 & -1.358707431 \\
\hline RBM25 & 1.63291277 & 6.324655258 & 8.650201845 & $2.17 \mathrm{E}-09$ & $1.18 \mathrm{E}-07$ & 11.5511557 \\
\hline TYROBP & 1.630051539 & 7.893243583 & 5.141218255 & $1.90 \mathrm{E}-05$ & 0.00012023 & 2.563038692 \\
\hline DACH1 & 1.623091259 & 7.101855154 & 6.801703043 & $2.20 \mathrm{E}-07$ & $3.44 \mathrm{E}-06$ & 6.970537686 \\
\hline PSMC3 & 1.612543512 & 9.366600505 & 5.93353245 & $2.21 \mathrm{E}-06$ & $2.14 \mathrm{E}-05$ & 4.68711502 \\
\hline RBMS1 & 1.6103609 & 8.650805194 & 4.65105936 & $7.23 \mathrm{E}-05$ & 0.000362333 & 1.248105923 \\
\hline PGK1 & 1.607870056 & 10.36413941 & 5.403307466 & $9.28 \mathrm{E}-06$ & $6.73 \mathrm{E}-05$ & 3.267574125 \\
\hline NPEPPS & 1.606521068 & 8.421329051 & 7.835158094 & $1.58 \mathrm{E}-08$ & $4.88 \mathrm{E}-07$ & 9.585322216 \\
\hline PTPRB & 1.604906513 & 9.444331687 & 7.330988837 & 5.62E-08 & $1.23 \mathrm{E}-06$ & 8.325736785 \\
\hline TNPO1 & 1.599343907 & 9.775968964 & 8.87594367 & $1.27 \mathrm{E}-09$ & $8.10 \mathrm{E}-08$ & 12.07966014 \\
\hline EZR & 1.591497713 & 8.757810465 & 5.97334531 & $1.98 \mathrm{E}-06$ & $1.97 \mathrm{E}-05$ & 4.793136085 \\
\hline MAGED2 & 1.586605561 & 10.30790428 & 12.89378949 & $2.78 \mathrm{E}-13$ & $2.81 \mathrm{E}-10$ & 20.3466641 \\
\hline ANKRD12 & 1.580638115 & 7.392354398 & 6.693843176 & 2.92E-07 & $4.26 \mathrm{E}-06$ & 6.690596121 \\
\hline FNBP1 & 1.575997647 & 8.157390697 & 8.31499427 & 4.86E-09 & $2.10 \mathrm{E}-07$ & 10.75349206 \\
\hline NR4A2 & -1.57481871 & 6.24079609 & -8.527861329 & $2.91 \mathrm{E}-09$ & $1.45 \mathrm{E}-07$ & 11.26180965 \\
\hline SERBP1 & 1.573844316 & 8.951883468 & 11.22792569 & $7.23 \mathrm{E}-12$ & 2.19E-09 & 17.17193154 \\
\hline SPAG9 & 1.573771613 & 5.928584131 & 12.82512531 & $3.16 \mathrm{E}-13$ & $2.98 \mathrm{E}-10$ & 20.22233593 \\
\hline SCAMP1 & 1.572326984 & 7.135740239 & 7.680340099 & 2.32E-08 & $6.50 \mathrm{E}-07$ & 9.201956772 \\
\hline RAB1A & 1.571530153 & 8.448144883 & 6.477980274 & $5.16 \mathrm{E}-07$ & $6.71 \mathrm{E}-06$ & 6.126856918 \\
\hline TAOK3 & 1.570396428 & 7.085559648 & 9.345798665 & $4.28 \mathrm{E}-10$ & $3.85 \mathrm{E}-08$ & 13.15714066 \\
\hline SRGN & 1.568368396 & 9.423138514 & 5.18175814 & $1.70 \mathrm{E}-05$ & 0.000109899 & 2.672037194 \\
\hline ZFYVE21 & 1.5676445 & 6.846082627 & 7.262978403 & $6.69 \mathrm{E}-08$ & $1.40 \mathrm{E}-06$ & 8.153414092 \\
\hline HRG & -1.562922635 & 8.320562127 & -4.315974661 & 0.000179859 & 0.000770138 & 0.357348521 \\
\hline PWP1 & 1.561834997 & 8.446947472 & 8.857117309 & 1.33E-09 & $8.24 \mathrm{E}-08$ & 12.03585221 \\
\hline SKAP2 & 1.561530224 & 9.277742191 & 7.33501641 & $5.57 \mathrm{E}-08$ & $1.22 \mathrm{E}-06$ & 8.335924267 \\
\hline UBXN4 & 1.551349919 & 9.105993907 & 6.390043816 & $6.51 \mathrm{E}-07$ & 8.06E-06 & 5.895950838 \\
\hline PECAM1 & 1.550870521 & 9.054536986 & 6.663178499 & $3.17 \mathrm{E}-07$ & 4.53E-06 & 6.610791348 \\
\hline MBNL2 & 1.550572397 & 7.066502239 & 10.39994319 & 4.12E-11 & 7.62E-09 & 15.46422432 \\
\hline SOX9 & -1.548564432 & 8.004071342 & -6.562764085 & 4.13E-07 & $5.60 \mathrm{E}-06$ & 6.348811078 \\
\hline TRIM2 & 1.546572067 & 8.578770031 & 8.831695492 & $1.41 \mathrm{E}-09$ & 8.68E-08 & 11.97661948 \\
\hline HNRNPR & 1.545721471 & 9.080452193 & 10.58685737 & $2.76 \mathrm{E}-11$ & 5.70E-09 & 15.85761598 \\
\hline MYOF & 1.54258444 & 8.617870178 & 7.043673577 & $1.18 \mathrm{E}-07$ & $2.13 \mathrm{E}-06$ & 7.594032778 \\
\hline $\mathrm{NR} 3 \mathrm{C} 1$ & 1.537314952 & 8.658438842 & 7.183782173 & $8.20 \mathrm{E}-08$ & $1.62 \mathrm{E}-06$ & 7.95205499 \\
\hline TFPI2 & 1.530489929 & 8.411366859 & 3.999919431 & 0.000421606 & 0.001565513 & -0.471022596 \\
\hline TMEM47 & 1.524753951 & 8.263583054 & 6.004266035 & $1.83 \mathrm{E}-06$ & $1.84 \mathrm{E}-05$ & 4.875407299 \\
\hline PURA & 1.522929493 & 7.624254878 & 6.128405127 & $1.31 \mathrm{E}-06$ & $1.41 \mathrm{E}-05$ & 5.20504847 \\
\hline RAB31 & 1.519313807 & 8.597342752 & 6.411935462 & $6.15 \mathrm{E}-07$ & 7.72E-06 & 5.95349937 \\
\hline CYB5B & 1.515075529 & 7.815221603 & 11.7624269 & $2.46 \mathrm{E}-12$ & $1.16 \mathrm{E}-09$ & 18.22746762 \\
\hline RIT1 & 1.514871553 & 7.235874533 & 7.407198303 & 4.63E-08 & $1.07 \mathrm{E}-06$ & 8.518169631 \\
\hline PRPF31 & 1.51015233 & 6.970023854 & 7.948526057 & $1.19 \mathrm{E}-08$ & $4.05 \mathrm{E}-07$ & 9.864072564 \\
\hline ALDOB & -1.504568555 & 8.472159452 & -3.061872507 & 0.004824275 & 0.012090824 & -2.80464753 \\
\hline MAP4 & 1.503555867 & 8.031894594 & 5.975611845 & $1.97 \mathrm{E}-06$ & $1.96 \mathrm{E}-05$ & 4.799168802 \\
\hline RAB2A & -1.502751043 & 8.315889782 & -16.2138848 & $9.61 \mathrm{E}-16$ & $9.51 \mathrm{E}-12$ & 25.7672033 \\
\hline
\end{tabular}


Huang Z (2019) Novel Pathology-Related Hub Genes in Focal Segmental Glomerulosclerosis

\begin{tabular}{|c|c|c|c|c|c|c|}
\hline gene.symbols & $\log F C$ & AveExpr & ts & P.Value & adj.P.Val & B \\
\hline BTN3A2 & 1.502705438 & 7.877942556 & 6.982291597 & $1.38 \mathrm{E}-07$ & $2.40 \mathrm{E}-06$ & 7.436477371 \\
\hline GMDS & 1.497770885 & 9.599429406 & 7.605970724 & $2.80 \mathrm{E}-08$ & 7.39E-07 & 9.016708396 \\
\hline CD163 & 1.496518651 & 7.363641477 & 3.780358703 & 0.000756817 & 0.002538255 & -1.036824644 \\
\hline PKN2 & 1.492252244 & 7.396561746 & 9.26254208 & $5.18 \mathrm{E}-10$ & $4.46 \mathrm{E}-08$ & 12.96843728 \\
\hline PICALM & 1.48883338 & 7.452309182 & 7.882640103 & $1.40 \mathrm{E}-08$ & $4.50 \mathrm{E}-07$ & 9.702276208 \\
\hline LYN & 1.48458898 & 7.748906756 & 6.995137981 & $1.33 \mathrm{E}-07$ & $2.35 \mathrm{E}-06$ & 7.469486452 \\
\hline ARL6IP5 & 1.481819394 & 9.42435093 & 6.181264534 & $1.14 \mathrm{E}-06$ & $1.26 \mathrm{E}-05$ & 5.345073096 \\
\hline SH3BP5 & 1.480757339 & 9.948617496 & 7.175018224 & $8.38 \mathrm{E}-08$ & $1.65 \mathrm{E}-06$ & 7.929726958 \\
\hline CYTH2 & 1.478569815 & 8.695293012 & 14.0977443 & $3.17 \mathrm{E}-14$ & $7.84 \mathrm{E}-11$ & 22.44167418 \\
\hline HSP90AA1 & 1.475101446 & 10.7822491 & 5.488461362 & 7.36E-06 & $5.62 \mathrm{E}-05$ & 3.49626449 \\
\hline PDPK1 & 1.474624621 & 8.188917333 & 5.243240876 & $1.44 \mathrm{E}-05$ & $9.60 \mathrm{E}-05$ & 2.837346192 \\
\hline SMC3 & 1.470872089 & 7.133595994 & 11.12401077 & $8.96 \mathrm{E}-12$ & $2.41 \mathrm{E}-09$ & 16.96251038 \\
\hline MBTPS1 & 1.465393655 & 8.496997806 & 7.766899015 & $1.87 \mathrm{E}-08$ & $5.53 \mathrm{E}-07$ & 9.416678054 \\
\hline TIMP3 & 1.463150322 & 9.290336056 & 7.335248955 & $5.56 \mathrm{E}-08$ & $1.22 \mathrm{E}-06$ & 8.336512413 \\
\hline SSRP1 & 1.462015221 & 7.615804716 & 9.043612741 & $8.60 \mathrm{E}-10$ & $6.37 \mathrm{E}-08$ & 12.46766016 \\
\hline NAA35 & 1.458486577 & 6.726259229 & 8.092465915 & 8.37E-09 & $3.11 \mathrm{E}-07$ & 10.21555345 \\
\hline KIF5B & 1.454182588 & 8.394875765 & 5.616323045 & $5.20 \mathrm{E}-06$ & $4.27 \mathrm{E}-05$ & 3.839255868 \\
\hline DHRS7 & 1.454116053 & 7.744616405 & 9.572938924 & $2.56 \mathrm{E}-10$ & $2.65 \mathrm{E}-08$ & 13.66709981 \\
\hline CNPY2 & 1.453764841 & 8.534477403 & 8.634059418 & 2.26E-09 & $1.20 \mathrm{E}-07$ & 11.51309488 \\
\hline FKBP5 & 1.452723718 & 7.291698701 & 4.149986734 & 0.000281682 & 0.001116854 & -0.079470163 \\
\hline COL6A3 & 1.447501816 & 7.827000817 & 4.905985588 & $3.61 \mathrm{E}-05$ & 0.000203504 & 1.930987853 \\
\hline COL4A2 & 1.446665268 & 7.456526747 & 6.876736022 & $1.81 \mathrm{E}-07$ & $2.96 \mathrm{E}-06$ & 7.164560203 \\
\hline CALB1 & -1.44533189 & 9.757638848 & -2.605850418 & 0.01452899 & 0.030801016 & -3.831208449 \\
\hline IGF1 & -1.437115619 & 9.406113438 & -3.336824653 & 0.002407335 & 0.006723822 & -2.146238464 \\
\hline NELFCD & 1.434489749 & 9.91051469 & 11.67139035 & $2.95 \mathrm{E}-12$ & $1.22 \mathrm{E}-09$ & 18.0502204 \\
\hline YWHAB & 1.431615777 & 8.640142735 & 5.544355542 & $6.32 \mathrm{E}-06$ & $5.00 \mathrm{E}-05$ & 3.646268215 \\
\hline RGCC & 1.429769752 & 7.679603868 & 4.732902335 & $5.78 \mathrm{E}-05$ & 0.000299666 & 1.466986783 \\
\hline SLC25A6 & 1.428984166 & 11.61631244 & 9.101576376 & $7.52 \mathrm{E}-10$ & $5.75 \mathrm{E}-08$ & 12.60089001 \\
\hline ID3 & 1.428233521 & 10.14589451 & 8.266105018 & $5.47 \mathrm{E}-09$ & $2.29 \mathrm{E}-07$ & 10.63587854 \\
\hline TRA2B & 1.424948669 & 9.497698712 & 8.624014607 & $2.31 \mathrm{E}-09$ & $1.22 \mathrm{E}-07$ & 11.48939306 \\
\hline GDI2 & 1.424531564 & 9.161869349 & 6.615965347 & $3.59 \mathrm{E}-07$ & 4.97E-06 & 6.48773575 \\
\hline CRHBP & 1.423223574 & 10.85750131 & 3.501852173 & 0.001572242 & 0.004679346 & -1.739506163 \\
\hline EID1 & 1.422600712 & 9.21370437 & 7.376173329 & $5.01 \mathrm{E}-08$ & $1.13 \mathrm{E}-06$ & 8.439915301 \\
\hline SET & 1.420718447 & 10.19887727 & 8.55531067 & 2.73E-09 & $1.37 \mathrm{E}-07$ & 11.32690802 \\
\hline FOS & -1.420440832 & 9.273302043 & -3.000916158 & 0.005612259 & 0.013756238 & -2.946942453 \\
\hline VDAC1 & 1.415009019 & 8.172894871 & 7.118018567 & $9.71 \mathrm{E}-08$ & $1.85 \mathrm{E}-06$ & 7.784289799 \\
\hline WASHC4 & 1.412990786 & 7.331446343 & 8.01490027 & $1.01 \mathrm{E}-08$ & $3.56 \mathrm{E}-07$ & 10.02649009 \\
\hline UMOD & -1.412526572 & 11.37016849 & -2.38566243 & 0.024069305 & 0.047104894 & -4.291378203 \\
\hline SERTAD2 & 1.411604795 & 8.175798374 & 8.513812449 & 3.01E-09 & $1.48 \mathrm{E}-07$ & 11.22845173 \\
\hline PQBP1 & 1.411256434 & 7.748400335 & 6.769612323 & $2.40 \mathrm{E}-07$ & $3.68 \mathrm{E}-06$ & 6.887374717 \\
\hline CEP350 & 1.409862497 & 6.337432566 & 7.135793044 & $9.27 \mathrm{E}-08$ & $1.79 \mathrm{E}-06$ & 7.829682626 \\
\hline GLYAT & -1.407015938 & 9.579743485 & -4.089844356 & 0.000331191 & 0.001276585 & -0.236812106 \\
\hline ICAM2 & 1.406910331 & 9.771163793 & 5.247150209 & $1.42 \mathrm{E}-05$ & $9.52 \mathrm{E}-05$ & 2.84785686 \\
\hline
\end{tabular}


Huang Z (2019) Novel Pathology-Related Hub Genes in Focal Segmental Glomerulosclerosis

\begin{tabular}{|c|c|c|c|c|c|c|}
\hline gene.symbols & $\log F C$ & AveExpr & ts & P.Value & adj.P.Val & B \\
\hline GNB1 & 1.402945544 & 9.130430125 & 10.649444 & $2.42 \mathrm{E}-11$ & 5.13E-09 & 15.98830239 \\
\hline HLA-DMB & 1.401194865 & 10.17298113 & 8.848947598 & $1.36 \mathrm{E}-09$ & 8.38E-08 & 12.01682652 \\
\hline EDNRB & 1.398466757 & 8.373823696 & 4.94196731 & $3.27 \mathrm{E}-05$ & 0.000188026 & 2.02759004 \\
\hline ESF1 & 1.398047621 & 7.471743775 & 13.05457765 & $2.06 \mathrm{E}-13$ & $2.30 \mathrm{E}-10$ & 20.63569798 \\
\hline AIDA & 1.397041007 & 7.692499594 & 8.873300307 & $1.28 \mathrm{E}-09$ & $8.11 \mathrm{E}-08$ & 12.07351212 \\
\hline TOP1 & 1.396150489 & 8.310821776 & 7.122657614 & $9.59 \mathrm{E}-08$ & $1.83 \mathrm{E}-06$ & 7.796140615 \\
\hline SNX1 & 1.393315129 & 7.77005298 & 9.617845685 & $2.31 \mathrm{E}-10$ & $2.46 \mathrm{E}-08$ & 13.76708049 \\
\hline CLDND1 & 1.389278478 & 8.356235731 & 7.353059136 & 5.32E-08 & $1.18 \mathrm{E}-06$ & 8.381538064 \\
\hline TSPAN3 & 1.38922393 & 9.719295375 & 4.512799487 & 0.000105387 & 0.000495607 & 0.879374553 \\
\hline SLC7A8 & 1.388681022 & 9.335582412 & 4.354999431 & 0.000161804 & 0.000706402 & 0.460535324 \\
\hline ARHGAP5 & -1.388500976 & 8.373041869 & -8.710601093 & $1.88 \mathrm{E}-09$ & $1.07 \mathrm{E}-07$ & 11.69324854 \\
\hline ILF3 & 1.386329503 & 6.940492403 & 8.230768777 & 5.97E-09 & $2.45 \mathrm{E}-07$ & 10.55066888 \\
\hline ATG12 & 1.384776561 & 7.242819619 & 7.607340868 & $2.79 \mathrm{E}-08$ & 7.39E-07 & 9.020127669 \\
\hline ZNF148 & 1.382618168 & 8.099582442 & 12.45022932 & $6.42 \mathrm{E}-13$ & $4.62 \mathrm{E}-10$ & 19.53391159 \\
\hline DLC1 & 1.379754481 & 9.408529743 & 8.406044121 & $3.90 \mathrm{E}-09$ & $1.80 \mathrm{E}-07$ & 10.97166939 \\
\hline MYDGF & 1.379051924 & 8.854924998 & 9.767015768 & $1.65 \mathrm{E}-10$ & $1.97 \mathrm{E}-08$ & 14.09720669 \\
\hline PSD3 & 1.379024578 & 6.766600545 & 5.210698818 & $1.57 \mathrm{E}-05$ & 0.000103008 & 2.749850991 \\
\hline CDC37 & 1.377078992 & 9.468182931 & 10.45472383 & 3.67E-11 & 7.04E-09 & 15.58000157 \\
\hline KPNB1 & 1.376929789 & 9.458847188 & 9.024827414 & $8.99 \mathrm{E}-10$ & $6.56 \mathrm{E}-08$ & 12.4243824 \\
\hline FOXN3 & 1.375967793 & 6.83901797 & 8.165674647 & $6.99 \mathrm{E}-09$ & $2.76 \mathrm{E}-07$ & 10.39326148 \\
\hline LIMCH1 & 1.375409137 & 9.097684708 & 5.56555133 & $5.97 \mathrm{E}-06$ & 4.77E-05 & 3.703125677 \\
\hline MLEC & 1.374524107 & 9.243909884 & 6.009168559 & $1.80 \mathrm{E}-06$ & $1.82 \mathrm{E}-05$ & 4.888445732 \\
\hline FABP5 & 1.370563815 & 7.473351905 & 3.638781888 & 0.001099405 & 0.003461152 & -1.396367326 \\
\hline SCNN1A & -1.367945371 & 9.167955994 & -4.114464255 & 0.000309965 & 0.001210427 & -0.172467464 \\
\hline TPR & 1.367879082 & 8.216314258 & 4.77899159 & $5.10 \mathrm{E}-05$ & 0.000270724 & 1.590412014 \\
\hline HSP90AB1 & 1.36640902 & 9.19132412 & 5.419142441 & 8.89E-06 & $6.51 \mathrm{E}-05$ & 3.310113519 \\
\hline $\mathrm{ABCF} 2$ & 1.364898619 & 7.12749747 & 8.687031396 & $1.99 \mathrm{E}-09$ & $1.11 \mathrm{E}-07$ & 11.63785903 \\
\hline HNRNPD & 1.36405605 & 9.094619756 & 8.738208165 & $1.76 \mathrm{E}-09$ & $1.02 \mathrm{E}-07$ & 11.75802893 \\
\hline TGFBR2 & 1.362070619 & 7.153715484 & 5.381838143 & $9.84 \mathrm{E}-06$ & 7.03E-05 & 3.209890462 \\
\hline $\mathrm{CD} 14$ & 1.361767811 & 8.618764289 & 5.636868061 & 4.92E-06 & 4.09E-05 & 3.894313936 \\
\hline FRZB & 1.361170602 & 9.126704666 & 5.082735903 & $2.22 \mathrm{E}-05$ & 0.000137296 & 2.405816869 \\
\hline BBS4 & 1.360150632 & 7.202996413 & 8.971308938 & $1.02 \mathrm{E}-09$ & 7.08E-08 & 12.30081903 \\
\hline HLA-G & 1.359808391 & 10.72098347 & 5.244182836 & 1.43E-05 & $9.58 \mathrm{E}-05$ & 2.839878762 \\
\hline SWAP70 & 1.359427598 & 9.113593244 & 5.306026158 & $1.21 \mathrm{E}-05$ & 8.33E-05 & 3.006138059 \\
\hline TNPO3 & 1.358231729 & 7.693616767 & 10.42872351 & $3.88 \mathrm{E}-11$ & 7.26E-09 & 15.52510066 \\
\hline LACTB2 & -1.355852383 & 7.530616 & -6.671617676 & $3.10 \mathrm{E}-07$ & $4.45 \mathrm{E}-06$ & 6.632763722 \\
\hline CEP57 & 1.352993373 & 5.052119046 & 12.37324173 & $7.44 \mathrm{E}-13$ & $4.88 \mathrm{E}-10$ & 19.39050197 \\
\hline MYO6 & 1.352421261 & 9.176047271 & 5.255177235 & $1.39 \mathrm{E}-05$ & $9.36 \mathrm{E}-05$ & 2.869438127 \\
\hline EPRS & 1.351852256 & 8.607022753 & 8.649814499 & $2.17 \mathrm{E}-09$ & $1.18 \mathrm{E}-07$ & 11.55024283 \\
\hline LRBA & -1.349799955 & 8.811192382 & -8.795602403 & $1.54 \mathrm{E}-09$ & $9.30 \mathrm{E}-08$ & 11.8923698 \\
\hline CXCR4 & 1.347649061 & 8.222517485 & 3.684201964 & 0.000975644 & 0.003135087 & -1.281519314 \\
\hline SRRM2 & 1.347568684 & 8.460042382 & 5.001654871 & $2.78 \mathrm{E}-05$ & 0.000165066 & 2.187913815 \\
\hline RPLP0 & 1.34749233 & 11.59881981 & 12.16742107 & $1.11 \mathrm{E}-12$ & $6.17 \mathrm{E}-10$ & 19.00364445 \\
\hline
\end{tabular}


Huang Z (2019) Novel Pathology-Related Hub Genes in Focal Segmental Glomerulosclerosis

\begin{tabular}{|c|c|c|c|c|c|c|}
\hline gene.symbols & $\log F C$ & AveExpr & ts & P.Value & adj.P.Val & B \\
\hline ITGA8 & 1.343209501 & 8.187995584 & 5.506346749 & 7.01E-06 & $5.43 \mathrm{E}-05$ & 3.544273858 \\
\hline DDX39A & 1.342371076 & 8.373749992 & 14.91487814 & $7.84 \mathrm{E}-15$ & $2.61 \mathrm{E}-11$ & 23.77683811 \\
\hline SSBP2 & 1.341694376 & 8.032258834 & 10.36379012 & $4.46 \mathrm{E}-11$ & 8.01E-09 & 15.38759602 \\
\hline HMGCR & 1.340708611 & 7.991412194 & 7.949010066 & $1.19 \mathrm{E}-08$ & $4.05 \mathrm{E}-07$ & 9.865259037 \\
\hline STX11 & 1.338253755 & 6.131744045 & 8.963225837 & $1.04 \mathrm{E}-09$ & 7.12E-08 & 12.28212241 \\
\hline TTF1 & 1.335503511 & 7.454129952 & 7.565990872 & $3.10 \mathrm{E}-08$ & $7.95 \mathrm{E}-07$ & 8.916832104 \\
\hline AZIN1 & 1.331515063 & 6.892036517 & 13.60307467 & $7.59 \mathrm{E}-14$ & $1.17 \mathrm{E}-10$ & 21.59996308 \\
\hline OAS1 & 1.328744906 & 7.180037476 & 4.581369291 & $8.74 \mathrm{E}-05$ & 0.000424389 & 1.062067683 \\
\hline PLEKHB1 & -1.325016546 & 7.570574431 & -8.601436826 & 2.44E-09 & $1.27 \mathrm{E}-07$ & 11.43606785 \\
\hline TMEM230 & 1.322637972 & 8.978392691 & 6.664841119 & $3.15 \mathrm{E}-07$ & 4.52E-06 & 6.615120736 \\
\hline BMPR2 & 1.321446254 & 6.459157792 & 7.530440342 & 3.39E-08 & $8.48 \mathrm{E}-07$ & 8.827852131 \\
\hline ZNF207 & 1.320509797 & 9.748881671 & 7.924554461 & $1.27 \mathrm{E}-08$ & $4.20 \mathrm{E}-07$ & 9.805271384 \\
\hline RAD21 & 1.320165778 & 7.728846175 & 7.217996731 & $7.51 \mathrm{E}-08$ & $1.53 \mathrm{E}-06$ & 8.039137581 \\
\hline HCLS1 & 1.318686529 & 9.088478783 & 7.557331729 & $3.17 \mathrm{E}-08$ & 8.09E-07 & 8.895173607 \\
\hline COG7 & 1.318315987 & 7.957007308 & 6.947663903 & $1.51 \mathrm{E}-07$ & $2.60 \mathrm{E}-06$ & 7.34740937 \\
\hline TSPAN5 & 1.317168741 & 7.574432985 & 7.172334408 & $8.44 \mathrm{E}-08$ & $1.66 \mathrm{E}-06$ & 7.922887565 \\
\hline CALR & -1.316887257 & 9.46952319 & -6.187797543 & $1.12 \mathrm{E}-06$ & $1.24 \mathrm{E}-05$ & 5.362364282 \\
\hline CASP1 & 1.315406814 & 7.280061706 & 6.917554285 & $1.63 \mathrm{E}-07$ & $2.75 \mathrm{E}-06$ & 7.269855086 \\
\hline CD53 & 1.314626339 & 9.310209635 & 4.82374315 & $4.51 \mathrm{E}-05$ & 0.000244358 & 1.710352793 \\
\hline STAT1 & 1.311254404 & 7.989702392 & 8.164628307 & 7.01E-09 & $2.76 \mathrm{E}-07$ & 10.39072663 \\
\hline NASP & 1.311023485 & 8.658422087 & 8.195333579 & $6.50 \mathrm{E}-09$ & $2.59 \mathrm{E}-07$ & 10.46505182 \\
\hline ATF3 & -1.309777911 & 9.32422844 & -4.436888056 & 0.000129551 & 0.000586505 & 0.677587657 \\
\hline LRRFIP1 & 1.308595239 & 9.842768068 & 6.02460185 & $1.73 \mathrm{E}-06$ & $1.77 \mathrm{E}-05$ & 4.929480606 \\
\hline BLVRA & 1.307890164 & 7.463070636 & 7.883905699 & $1.40 \mathrm{E}-08$ & 4.49E-07 & 9.705389497 \\
\hline TRAM2 & 1.307573251 & 8.603172154 & 6.048923045 & $1.62 \mathrm{E}-06$ & $1.68 \mathrm{E}-05$ & 4.994114324 \\
\hline SPTLC1 & 1.306960571 & 7.365444445 & 8.208877143 & $6.29 \mathrm{E}-09$ & $2.54 \mathrm{E}-07$ & 10.49779515 \\
\hline COL4A3 & 1.303589773 & 10.63769098 & 5.004570724 & $2.75 \mathrm{E}-05$ & 0.000164118 & 2.195748058 \\
\hline DDX41 & 1.303536766 & 9.473571199 & 11.00669283 & $1.14 \mathrm{E}-11$ & 2.94E-09 & 16.72440575 \\
\hline ACTR3 & 1.302268329 & 10.75060111 & 7.097878642 & $1.02 \mathrm{E}-07$ & $1.93 \mathrm{E}-06$ & 7.732811998 \\
\hline ACLY & 1.302204054 & 8.910503391 & 7.337433307 & $5.53 \mathrm{E}-08$ & $1.22 \mathrm{E}-06$ & 8.342036709 \\
\hline FNTA & 1.301806985 & 9.235960273 & 8.985880851 & $9.85 \mathrm{E}-10$ & $6.90 \mathrm{E}-08$ & 12.33450181 \\
\hline FCN1 & 1.301737217 & 7.825729707 & 4.507676388 & 0.000106866 & 0.000500799 & 0.865740298 \\
\hline GPM6B & 1.30102056 & 7.554873441 & 5.23789948 & $1.46 \mathrm{E}-05$ & $9.70 \mathrm{E}-05$ & 2.822985149 \\
\hline NUDC & 1.299825767 & 10.1129032 & 9.124297995 & $7.13 \mathrm{E}-10$ & $5.57 \mathrm{E}-08$ & 12.65298921 \\
\hline PHB & 1.299280352 & 9.036698753 & 8.34467426 & $4.52 \mathrm{E}-09$ & $2.00 \mathrm{E}-07$ & 10.82473593 \\
\hline USP1 & 1.299122208 & 5.712328518 & 6.903628133 & $1.69 \mathrm{E}-07$ & $2.81 \mathrm{E}-06$ & 7.233951504 \\
\hline UGCG & 1.299100428 & 7.637255196 & 6.564098659 & $4.11 \mathrm{E}-07$ & $5.59 \mathrm{E}-06$ & 6.352299401 \\
\hline NUP88 & 1.298049189 & 7.778731314 & 11.63242519 & $3.19 \mathrm{E}-12$ & $1.26 \mathrm{E}-09$ & 17.97404068 \\
\hline LEPROT & 1.297113978 & 11.60207857 & 4.961828441 & $3.10 \mathrm{E}-05$ & 0.000180137 & 2.080928206 \\
\hline SORD & -1.296373291 & 9.712182519 & -3.408042698 & 0.002004522 & 0.00576643 & -1.971684138 \\
\hline RNASEH1 & 1.296211957 & 8.062974187 & 7.743815272 & $1.98 \mathrm{E}-08$ & $5.73 \mathrm{E}-07$ & 9.359509858 \\
\hline BGN & -1.293749031 & 10.83426956 & -5.497336355 & 7.19E-06 & $5.53 \mathrm{E}-05$ & 3.520088593 \\
\hline EPB41L1 & -1.293565904 & 8.131970301 & -8.910275853 & $1.18 \mathrm{E}-09$ & 7.65E-08 & 12.15942346 \\
\hline
\end{tabular}


Huang Z (2019) Novel Pathology-Related Hub Genes in Focal Segmental Glomerulosclerosis

\begin{tabular}{|c|c|c|c|c|c|c|}
\hline gene.symbols & $\log F C$ & AveExpr & ts & P.Value & adj.P.Val & B \\
\hline NT5DC2 & 1.290854598 & 7.006657669 & 5.49509333 & 7.23E-06 & $5.55 \mathrm{E}-05$ & 3.514067608 \\
\hline EIF5 & 1.290509517 & 9.992535565 & 5.777169499 & $3.37 \mathrm{E}-06$ & $3.01 \mathrm{E}-05$ & 4.26981525 \\
\hline JUND & -1.288819693 & 11.17357526 & -13.61921949 & $7.38 \mathrm{E}-14$ & $1.17 \mathrm{E}-10$ & 21.62784642 \\
\hline PLK2 & 1.287415552 & 7.339410911 & 5.759288171 & $3.53 \mathrm{E}-06$ & $3.14 \mathrm{E}-05$ & 4.222009283 \\
\hline M6PR & 1.286522924 & 7.51082701 & 7.771500991 & $1.85 \mathrm{E}-08$ & $5.49 \mathrm{E}-07$ & 9.428066888 \\
\hline DHRS7B & 1.286003609 & 9.123234779 & 8.514469828 & $3.01 \mathrm{E}-09$ & $1.48 \mathrm{E}-07$ & 11.23001323 \\
\hline TCF7L1 & -1.284417857 & 9.471134171 & -6.21840816 & $1.03 \mathrm{E}-06$ & $1.16 \mathrm{E}-05$ & 5.443338468 \\
\hline TMEM140 & 1.284344829 & 9.254354193 & 10.94233816 & $1.31 \mathrm{E}-11$ & $3.20 \mathrm{E}-09$ & 16.59303621 \\
\hline CYP27B1 & -1.28385958 & 8.032205684 & -5.997251595 & $1.86 \mathrm{E}-06$ & $1.87 \mathrm{E}-05$ & 4.856749376 \\
\hline KRAS & 1.281495706 & 8.377790663 & 6.362344392 & 7.01E-07 & $8.55 \mathrm{E}-06$ & 5.823074564 \\
\hline GMFG & 1.279945687 & 9.288317601 & 7.459463711 & 4.06E-08 & $9.68 \mathrm{E}-07$ & 8.64973168 \\
\hline PSMA3 & 1.279565875 & 10.16490647 & 5.83933803 & $2.85 \mathrm{E}-06$ & $2.64 \mathrm{E}-05$ & 4.435894253 \\
\hline CNOT2 & 1.279300816 & 8.782442522 & 6.434254514 & $5.79 \mathrm{E}-07$ & 7.35E-06 & 6.01212757 \\
\hline KLC1 & 1.277054189 & 9.104980272 & 7.524681574 & $3.44 \mathrm{E}-08$ & $8.56 \mathrm{E}-07$ & 8.813423521 \\
\hline PLPPR1 & -1.276165848 & 8.240622771 & -3.816088742 & 0.000688405 & 0.002344447 & -0.945391009 \\
\hline ABCG1 & 1.275777921 & 7.186008684 & 6.811441439 & $2.15 \mathrm{E}-07$ & 3.37E-06 & 6.995753313 \\
\hline DAZAP2 & 1.274142925 & 9.739018005 & 7.637559175 & $2.59 \mathrm{E}-08$ & 7.01E-07 & 9.095478672 \\
\hline ERLIN2 & -1.273846883 & 9.305200067 & -7.370850264 & $5.08 \mathrm{E}-08$ & $1.14 \mathrm{E}-06$ & 8.426477123 \\
\hline $\mathrm{GC}$ & -1.272445074 & 6.332951466 & -2.524545429 & 0.017546408 & 0.036095513 & -4.004098064 \\
\hline RNF13 & 1.268534955 & 10.26760703 & 5.355043954 & $1.06 \mathrm{E}-05$ & 7.48E-05 & 3.137888261 \\
\hline COL1A2 & 1.266974585 & 7.179573515 & 3.501641194 & 0.001573104 & 0.004681133 & -1.740031084 \\
\hline ZC3H15 & 1.266150743 & 9.172149178 & 5.200299793 & $1.61 \mathrm{E}-05$ & 0.000105414 & 2.721890801 \\
\hline КМТ5B & 1.265913904 & 8.649285188 & 7.46494521 & 4.00E-08 & $9.61 \mathrm{E}-07$ & 8.663510146 \\
\hline PUM1 & 1.263073454 & 8.134411951 & 6.955641137 & $1.48 \mathrm{E}-07$ & $2.55 \mathrm{E}-06$ & 7.367939869 \\
\hline ADD3 & 1.258422615 & 8.997988364 & 5.947988367 & 2.12E-06 & $2.08 \mathrm{E}-05$ & 4.725622462 \\
\hline KPNA2 & 1.255126625 & 8.907075287 & 6.720095976 & $2.73 \mathrm{E}-07$ & 4.03E-06 & 6.758843409 \\
\hline HLA-DMA & 1.254424027 & 10.37397051 & 5.785073702 & $3.29 \mathrm{E}-06$ & $2.96 \mathrm{E}-05$ & 4.290942076 \\
\hline THEMIS2 & 1.253798071 & 7.019422688 & 6.789113515 & $2.28 \mathrm{E}-07$ & $3.53 \mathrm{E}-06$ & 6.937924834 \\
\hline GNL3L & 1.252325393 & 7.124510447 & 10.81838227 & $1.69 \mathrm{E}-11$ & 3.89E-09 & 16.33847971 \\
\hline PSMB4 & 1.249957625 & 10.72159802 & 9.265970538 & $5.14 \mathrm{E}-10$ & 4.44E-08 & 12.97622687 \\
\hline AGMAT & -1.248270761 & 10.8536785 & -3.824270959 & 0.000673611 & 0.002304987 & -0.924415444 \\
\hline GIPC2 & -1.247317538 & 7.723359098 & -4.309932572 & 0.000182827 & 0.000781047 & 0.341387838 \\
\hline DHX9 & 1.246849962 & 6.351974134 & 7.128339548 & 9.45E-08 & $1.81 \mathrm{E}-06$ & 7.810652181 \\
\hline EWSR1 & 1.246648172 & 8.535866582 & 10.08327007 & $8.21 \mathrm{E}-11$ & 1.24E-08 & 14.78704752 \\
\hline SETD5 & 1.245898909 & 7.482287092 & 7.89652774 & $1.36 \mathrm{E}-08$ & $4.40 \mathrm{E}-07$ & 9.736427478 \\
\hline EIF4G1 & 1.244109972 & 7.486954023 & 8.936556557 & $1.10 \mathrm{E}-09$ & 7.39E-08 & 12.22037107 \\
\hline SRSF3 & 1.243986139 & 9.803111657 & 7.286475154 & $6.30 \mathrm{E}-08$ & $1.34 \mathrm{E}-06$ & 8.21301214 \\
\hline ILF2 & 1.243442066 & 9.552958146 & 6.68055437 & $3.03 \mathrm{E}-07$ & 4.37E-06 & 6.656023645 \\
\hline CYP26B1 & -1.242450416 & 8.634347541 & -2.397548309 & 0.02343442 & 0.046015965 & -4.26720407 \\
\hline SERPINE1 & 1.240736407 & 6.725458286 & 4.521128924 & 0.000103025 & 0.000486376 & 0.901546668 \\
\hline PSMD4 & 1.240423225 & 10.38557871 & 10.02544818 & $9.32 \mathrm{E}-11$ & $1.33 \mathrm{E}-08$ & 14.66193831 \\
\hline PDLIM3 & 1.239425245 & 7.796445864 & 8.153301921 & $7.21 \mathrm{E}-09$ & $2.81 \mathrm{E}-07$ & 10.36327807 \\
\hline TMEM87A & 1.238174918 & 8.636838914 & 8.683893986 & 2.01E-09 & $1.12 \mathrm{E}-07$ & 11.63048026 \\
\hline
\end{tabular}


Huang Z (2019) Novel Pathology-Related Hub Genes in Focal Segmental Glomerulosclerosis

\begin{tabular}{|c|c|c|c|c|c|c|}
\hline gene.symbols & $\log F C$ & AveExpr & ts & P.Value & adj.P.Val & B \\
\hline PRRC2C & 1.238003417 & 7.756011399 & 7.200125227 & $7.86 \mathrm{E}-08$ & $1.58 \mathrm{E}-06$ & 7.993668362 \\
\hline SNX4 & 1.237495753 & 7.321680798 & 7.530106662 & $3.39 \mathrm{E}-08$ & $8.48 \mathrm{E}-07$ & 8.827016208 \\
\hline NRP1 & 1.236313178 & 9.129569229 & 5.883209216 & $2.53 \mathrm{E}-06$ & $2.39 \mathrm{E}-05$ & 4.552965336 \\
\hline WAC & 1.235001654 & 7.03036538 & 7.197894999 & $7.90 \mathrm{E}-08$ & $1.58 \mathrm{E}-06$ & 7.98799151 \\
\hline SASH1 & 1.234739955 & 8.294239034 & 7.261823684 & $6.71 \mathrm{E}-08$ & $1.40 \mathrm{E}-06$ & 8.15048352 \\
\hline TAP1 & 1.234734308 & 9.251835212 & 8.342764658 & 4.55E-09 & $2.01 \mathrm{E}-07$ & 10.82015571 \\
\hline CHMP2A & 1.234514701 & 10.38085677 & 5.726260811 & $3.86 \mathrm{E}-06$ & $3.38 \mathrm{E}-05$ & 4.133668805 \\
\hline ARPC1B & 1.23312388 & 9.847594921 & 6.629826451 & $3.46 \mathrm{E}-07$ & $4.86 \mathrm{E}-06$ & 6.523885973 \\
\hline C1QA & 1.232874166 & 7.267276992 & 3.49242546 & 0.001611225 & 0.004776231 & -1.762948256 \\
\hline ZFPM2 & -1.231930712 & 8.037949772 & -5.308203625 & $1.20 \mathrm{E}-05$ & $8.29 \mathrm{E}-05$ & 3.011991311 \\
\hline APLP2 & 1.231910612 & 10.32603877 & 7.606109272 & $2.80 \mathrm{E}-08$ & 7.39E-07 & 9.017054163 \\
\hline UTP14A & 1.231347458 & 7.661719061 & 7.121605911 & $9.62 \mathrm{E}-08$ & $1.84 \mathrm{E}-06$ & 7.793454173 \\
\hline CAT & 1.229093195 & 8.87973752 & 6.872999304 & $1.83 \mathrm{E}-07$ & 2.99E-06 & 7.15491194 \\
\hline TIA1 & 1.227747542 & 7.247584903 & 9.010951208 & $9.29 \mathrm{E}-10$ & $6.61 \mathrm{E}-08$ & 12.39238301 \\
\hline NAGK & 1.22754899 & 9.926020105 & 10.36793433 & 4.42E-11 & $8.00 \mathrm{E}-09$ & 15.39638877 \\
\hline TM9SF1 & 1.227465595 & 8.623773028 & 8.253859905 & $5.64 \mathrm{E}-09$ & $2.34 \mathrm{E}-07$ & 10.60636978 \\
\hline GLG1 & 1.226621678 & 9.826971817 & 5.632513248 & $4.98 \mathrm{E}-06$ & $4.12 \mathrm{E}-05$ & 3.882644978 \\
\hline XPNPEP1 & 1.225389014 & 8.466825777 & 7.86771117 & $1.46 \mathrm{E}-08$ & $4.60 \mathrm{E}-07$ & 9.665536137 \\
\hline HYAL2 & 1.22355501 & 9.281267332 & 6.500981316 & $4.86 \mathrm{E}-07$ & $6.40 \mathrm{E}-06$ & 6.18713754 \\
\hline ASF1A & 1.223294692 & 7.739507727 & 7.51950823 & $3.48 \mathrm{E}-08$ & $8.66 \mathrm{E}-07$ & 8.80045816 \\
\hline WARS & 1.221822477 & 9.608411649 & 7.31487298 & $5.86 \mathrm{E}-08$ & $1.27 \mathrm{E}-06$ & 8.284953181 \\
\hline TMCO3 & 1.22011721 & 9.102616418 & 4.979257633 & $2.95 \mathrm{E}-05$ & 0.000173536 & 2.127743623 \\
\hline KTN1 & 1.218156632 & 6.898784102 & 5.40406927 & $9.26 \mathrm{E}-06$ & $6.72 \mathrm{E}-05$ & 3.269620769 \\
\hline NNT & 1.215568091 & 6.952880722 & 5.386246015 & $9.72 \mathrm{E}-06$ & $6.96 \mathrm{E}-05$ & 3.221734225 \\
\hline XPNPEP2 & -1.215559549 & 8.851730714 & -3.325159474 & 0.002480356 & 0.006893212 & -2.174682385 \\
\hline FLRT3 & 1.210792751 & 10.14839181 & 4.168211768 & 0.000268176 & 0.001070866 & -0.031686858 \\
\hline FADS3 & 1.209980177 & 7.375563699 & 8.103163063 & $8.15 \mathrm{E}-09$ & $3.06 \mathrm{E}-07$ & 10.24156454 \\
\hline ENO1 & 1.209953356 & 7.883385651 & 6.223548255 & $1.01 \mathrm{E}-06$ & $1.15 \mathrm{E}-05$ & 5.45692833 \\
\hline HLA-F & 1.209909743 & 11.83477086 & 8.124091232 & 7.74E-09 & $2.96 \mathrm{E}-07$ & 10.29240912 \\
\hline PTPRC & 1.208351307 & 5.832030673 & 8.047207456 & $9.35 \mathrm{E}-09$ & $3.38 \mathrm{E}-07$ & 10.10533478 \\
\hline SYT1 & -1.208255658 & 7.30889895 & -4.705882758 & $6.23 \mathrm{E}-05$ & 0.000319624 & 1.394681992 \\
\hline COMT & 1.206977299 & 9.312304131 & 7.752820425 & $1.94 \mathrm{E}-08$ & $5.66 \mathrm{E}-07$ & 9.381819803 \\
\hline PLS1 & -1.206303455 & 8.261543055 & -5.496977729 & 7.19E-06 & $5.53 \mathrm{E}-05$ & 3.519125937 \\
\hline ITGB2 & 1.205909695 & 7.91890843 & 5.254326121 & $1.39 \mathrm{E}-05$ & 9.37E-05 & 2.867149862 \\
\hline SMARCE1 & 1.205666484 & 8.972747998 & 7.373668132 & 5.04E-08 & $1.13 \mathrm{E}-06$ & 8.433591315 \\
\hline SEC14L1 & 1.205033056 & 7.939442936 & 6.08339441 & $1.48 \mathrm{E}-06$ & $1.55 \mathrm{E}-05$ & 5.085651874 \\
\hline POSTN & 1.201856865 & 10.82658185 & 3.379886179 & 0.00215532 & 0.006130585 & -2.040877409 \\
\hline DEFB1 & -1.200644494 & 10.99447884 & -3.02989907 & 0.005223435 & 0.012932645 & -2.879463619 \\
\hline TYRP1 & -1.200351272 & 6.207994431 & -3.539545898 & 0.001425307 & 0.004302374 & -1.645531253 \\
\hline IMP3 & 1.199878035 & 9.403506224 & 8.37029393 & $4.25 \mathrm{E}-09$ & $1.92 \mathrm{E}-07$ & 10.88613742 \\
\hline SMARCA2 & 1.199515299 & 6.947329006 & 7.267526219 & $6.61 \mathrm{E}-08$ & $1.38 \mathrm{E}-06$ & 8.164954491 \\
\hline AKAP8L & 1.199316813 & 6.916908369 & 7.807966077 & $1.69 \mathrm{E}-08$ & $5.14 \mathrm{E}-07$ & 9.518212724 \\
\hline PSMD13 & 1.198610121 & 8.052040062 & 10.25115059 & $5.69 \mathrm{E}-11$ & $9.46 \mathrm{E}-09$ & 15.14772671 \\
\hline
\end{tabular}


Huang Z (2019) Novel Pathology-Related Hub Genes in Focal Segmental Glomerulosclerosis

\begin{tabular}{|c|c|c|c|c|c|c|}
\hline gene.symbols & $\log F C$ & AveExpr & ts & P.Value & adj.P.Val & B \\
\hline COPS8 & 1.1970076 & 9.204275007 & 7.044000749 & $1.17 \mathrm{E}-07$ & $2.13 \mathrm{E}-06$ & 7.594871427 \\
\hline AKAP13 & 1.19666266 & 7.792140231 & 6.987365814 & $1.36 \mathrm{E}-07$ & $2.38 \mathrm{E}-06$ & 7.449517889 \\
\hline RRAD & 1.196066763 & 6.953293655 & 7.077275531 & $1.08 \mathrm{E}-07$ & 2.01E-06 & 7.680102108 \\
\hline PLEKHO1 & 1.195459638 & 7.723639306 & 7.159751859 & $8.72 \mathrm{E}-08$ & $1.70 \mathrm{E}-06$ & 7.89081119 \\
\hline FOLR1 & -1.193436488 & 6.956916716 & -3.734922458 & 0.000853477 & 0.002814152 & -1.152704059 \\
\hline PPIC & 1.192607632 & 8.477886659 & 6.960597292 & $1.46 \mathrm{E}-07$ & $2.53 \mathrm{E}-06$ & 7.380691668 \\
\hline SNX2 & 1.192127734 & 8.610500524 & 6.157301546 & $1.21 \mathrm{E}-06$ & $1.33 \mathrm{E}-05$ & 5.281621255 \\
\hline MBD4 & 1.185770843 & 8.009202546 & 7.069175367 & $1.10 \mathrm{E}-07$ & $2.03 \mathrm{E}-06$ & 7.659365794 \\
\hline AP3D1 & 1.18500723 & 8.6135603 & 7.725903422 & 2.07E-08 & $5.94 \mathrm{E}-07$ & 9.315102851 \\
\hline HBB & 1.184947119 & 11.93377932 & 3.343143234 & 0.002368653 & 0.006631573 & -2.130813886 \\
\hline RNF114 & 1.183206283 & 9.30418479 & 9.465288756 & $3.26 \mathrm{E}-10$ & $3.26 \mathrm{E}-08$ & 13.42629734 \\
\hline ABHD17A & 1.181106471 & 9.170196843 & 8.329715797 & 4.69E-09 & $2.06 \mathrm{E}-07$ & 10.78884453 \\
\hline LRRC42 & 1.180209467 & 7.573503367 & 8.941836312 & $1.09 \mathrm{E}-09$ & 7.34E-08 & 12.23260386 \\
\hline DDAH1 & -1.180008114 & 11.46433716 & -5.151767722 & $1.84 \mathrm{E}-05$ & 0.000117466 & 2.591402158 \\
\hline TSC22D3 & 1.179816234 & 8.262843013 & 4.224652868 & 0.000230275 & 0.000942027 & 0.116582968 \\
\hline GYG1 & 1.177529499 & 9.834468492 & 6.016373152 & $1.77 \mathrm{E}-06$ & $1.80 \mathrm{E}-05$ & 4.907603688 \\
\hline UQCRC2 & 1.176924599 & 9.899057439 & 7.23706376 & $7.15 \mathrm{E}-08$ & $1.47 \mathrm{E}-06$ & 8.087606913 \\
\hline FKBP11 & 1.176919235 & 8.727123226 & 6.266120256 & $9.06 \mathrm{E}-07$ & $1.04 \mathrm{E}-05$ & 5.569402926 \\
\hline TM4SF1 & 1.176815697 & 8.331708401 & 5.239153764 & $1.45 \mathrm{E}-05$ & $9.68 \mathrm{E}-05$ & 2.826357468 \\
\hline AHCYL1 & 1.176691914 & 8.745386211 & 5.330391797 & $1.13 \mathrm{E}-05$ & $7.91 \mathrm{E}-05$ & 3.071632149 \\
\hline SLC28A1 & -1.176464801 & 6.772070338 & -8.212773139 & $6.23 \mathrm{E}-09$ & $2.52 \mathrm{E}-07$ & 10.50720966 \\
\hline LGALS3 & 1.176104581 & 9.941755013 & 7.549802161 & $3.23 \mathrm{E}-08$ & $8.21 \mathrm{E}-07$ & 8.876332784 \\
\hline CAVIN2 & 1.174754505 & 6.982038785 & 5.495846891 & $7.22 \mathrm{E}-06$ & $5.54 \mathrm{E}-05$ & 3.516090419 \\
\hline SERPINH1 & 1.174275681 & 9.648430496 & 6.407521754 & $6.22 \mathrm{E}-07$ & 7.79E-06 & 5.941900078 \\
\hline ACTA2 & 1.173648029 & 10.38204081 & 5.932733912 & $2.21 \mathrm{E}-06$ & $2.15 \mathrm{E}-05$ & 4.684987509 \\
\hline HNRNPA2B1 & 1.173592582 & 11.06475641 & 9.665793594 & $2.07 \mathrm{E}-10$ & $2.28 \mathrm{E}-08$ & 13.87352619 \\
\hline AP1S2 & 1.172535127 & 8.523906337 & 5.252624432 & $1.40 \mathrm{E}-05$ & $9.41 \mathrm{E}-05$ & 2.862574763 \\
\hline PNN & 1.17087381 & 7.970795555 & 7.747188801 & $1.97 \mathrm{E}-08$ & $5.70 \mathrm{E}-07$ & 9.367868879 \\
\hline HLA-C & 1.169664398 & 10.16761106 & 7.595608208 & $2.88 \mathrm{E}-08$ & $7.54 \mathrm{E}-07$ & 8.990840477 \\
\hline PRPF4B & 1.169551009 & 6.935475927 & 5.67669604 & $4.42 \mathrm{E}-06$ & $3.75 \mathrm{E}-05$ & 4.000998961 \\
\hline USP48 & -1.168630772 & 9.038096545 & -7.747244509 & $1.97 \mathrm{E}-08$ & $5.70 \mathrm{E}-07$ & 9.368006903 \\
\hline MCM7 & 1.168505141 & 8.351995021 & 8.050385686 & $9.28 \mathrm{E}-09$ & $3.36 \mathrm{E}-07$ & 10.11308366 \\
\hline TUG1 & 1.168335892 & 9.165666062 & 6.054292701 & $1.60 \mathrm{E}-06$ & $1.66 \mathrm{E}-05$ & 5.008378733 \\
\hline CASP4 & 1.167446728 & 7.679803702 & 10.35532363 & $4.54 \mathrm{E}-11$ & 8.03E-09 & 15.36962558 \\
\hline FOXO3 & 1.167411973 & 8.567526997 & 5.725633219 & $3.87 \mathrm{E}-06$ & $3.38 \mathrm{E}-05$ & 4.131989636 \\
\hline VAMP2 & -1.166211897 & 7.442364851 & -7.873871112 & $1.43 \mathrm{E}-08$ & $4.56 \mathrm{E}-07$ & 9.680699271 \\
\hline PDIA6 & 1.165260403 & 10.67248004 & 5.899377478 & $2.42 \mathrm{E}-06$ & $2.31 \mathrm{E}-05$ & 4.596082594 \\
\hline DDOST & 1.164865434 & 10.9394614 & 6.470185623 & $5.27 \mathrm{E}-07$ & $6.83 \mathrm{E}-06$ & 6.10641779 \\
\hline PYCARD & 1.163566225 & 7.46929959 & 5.864762597 & $2.66 \mathrm{E}-06$ & $2.50 \mathrm{E}-05$ & 4.503753551 \\
\hline ZNF24 & 1.162861739 & 7.210438195 & 7.357297992 & $5.26 \mathrm{E}-08$ & $1.17 \mathrm{E}-06$ & 8.392248586 \\
\hline TYRO3 & 1.161757961 & 8.189575049 & 5.5953718 & $5.51 \mathrm{E}-06$ & $4.46 \mathrm{E}-05$ & 3.783092394 \\
\hline ADH6 & -1.16166635 & 8.207644366 & -3.436207702 & 0.001863907 & 0.005412229 & -1.902237878 \\
\hline ACSL3 & 1.16124775 & 8.408959315 & 3.546281515 & 0.001400494 & 0.004237233 & -1.628698861 \\
\hline
\end{tabular}


Huang Z (2019) Novel Pathology-Related Hub Genes in Focal Segmental Glomerulosclerosis

\begin{tabular}{|c|c|c|c|c|c|c|}
\hline gene.symbols & $\log F C$ & AveExpr & ts & P.Value & adj.P.Val & B \\
\hline PARP2 & 1.161143625 & 8.581427075 & 11.19875359 & $7.68 \mathrm{E}-12$ & $2.21 \mathrm{E}-09$ & 17.11328056 \\
\hline MCCC2 & -1.160816294 & 10.45719644 & -5.897428416 & $2.43 \mathrm{E}-06$ & $2.32 \mathrm{E}-05$ & 4.590885687 \\
\hline ZNF22 & 1.159131186 & 7.261181636 & 12.5812987 & $5.00 \mathrm{E}-13$ & $4.05 \mathrm{E}-10$ & 19.77645675 \\
\hline RALBP1 & 1.158724753 & 8.274230454 & 7.859219723 & $1.49 \mathrm{E}-08$ & $4.66 \mathrm{E}-07$ & 9.644625716 \\
\hline NUP85 & 1.156176785 & 8.422135666 & 9.538080515 & $2.77 \mathrm{E}-10$ & $2.81 \mathrm{E}-08$ & 13.5892997 \\
\hline CPD & 1.156112532 & 6.819716927 & 8.154881627 & 7.18E-09 & $2.81 \mathrm{E}-07$ & 10.36710738 \\
\hline $\mathrm{HCP} 5$ & 1.155541743 & 8.967916149 & 5.892526241 & $2.47 \mathrm{E}-06$ & $2.34 \mathrm{E}-05$ & 4.577813709 \\
\hline AGTR1 & 1.155149645 & 6.968562585 & 5.121576314 & $2.00 \mathrm{E}-05$ & 0.000125603 & 2.510230811 \\
\hline LIN37 & 1.155105526 & 6.577595527 & 9.667828073 & $2.06 \mathrm{E}-10$ & $2.28 \mathrm{E}-08$ & 13.87803581 \\
\hline ССТ6А & 1.154913313 & 9.14834035 & 7.235166054 & 7.18E-08 & $1.48 \mathrm{E}-06$ & 8.08278478 \\
\hline HNRNPC & 1.154717025 & 8.873047157 & 6.813932366 & $2.13 \mathrm{E}-07$ & $3.35 \mathrm{E}-06$ & 7.002201462 \\
\hline SLC13A1 & -1.15376563 & 7.5476979 & -3.18681201 & 0.003526296 & 0.009294589 & -2.508681404 \\
\hline VAMP3 & 1.152730555 & 7.405947549 & 4.957816762 & $3.13 \mathrm{E}-05$ & 0.000181512 & 2.070153776 \\
\hline MAP4K3 & -1.150486671 & 7.339441604 & -6.152728191 & $1.23 \mathrm{E}-06$ & $1.34 \mathrm{E}-05$ & 5.269506464 \\
\hline JMJD6 & 1.150291091 & 7.191119689 & 12.55420458 & $5.27 \mathrm{E}-13$ & $4.05 \mathrm{E}-10$ & 19.726484 \\
\hline HLA-DPB1 & 1.150218342 & 11.36426215 & 5.525706581 & $6.65 \mathrm{E}-06$ & $5.21 \mathrm{E}-05$ & 3.596230432 \\
\hline SRRM1 & -1.149363305 & 9.137180405 & -5.391189648 & $9.59 \mathrm{E}-06$ & $6.88 \mathrm{E}-05$ & 3.235017125 \\
\hline RRAGC & 1.149352733 & 8.837854366 & 6.475336686 & $5.20 \mathrm{E}-07$ & $6.75 \mathrm{E}-06$ & 6.119925528 \\
\hline ZNF804A & -1.149172983 & 8.504688414 & -5.863390141 & $2.67 \mathrm{E}-06$ & $2.50 \mathrm{E}-05$ & 4.500091338 \\
\hline PSME3 & -1.148471143 & 9.262437167 & -5.79437545 & $3.21 \mathrm{E}-06$ & $2.90 \mathrm{E}-05$ & 4.315800219 \\
\hline RBP4 & -1.148117964 & 8.285701455 & -2.430483745 & 0.021754392 & 0.043227525 & -4.199808903 \\
\hline NMD3 & 1.147678273 & 7.096738478 & 5.993365837 & $1.88 \mathrm{E}-06$ & $1.89 \mathrm{E}-05$ & 4.846412134 \\
\hline PSMB9 & 1.144615141 & 10.39353049 & 6.638465727 & $3.38 \mathrm{E}-07$ & $4.76 \mathrm{E}-06$ & 6.546407914 \\
\hline SYNCRIP & 1.144133474 & 7.533673599 & 5.254346869 & $1.39 \mathrm{E}-05$ & $9.37 \mathrm{E}-05$ & 2.867205645 \\
\hline YWHAH & 1.142268582 & 8.609758108 & 3.448365406 & 0.001806203 & 0.005267323 & -1.872190252 \\
\hline DNAJC8 & 1.141702145 & 9.890908337 & 12.41268851 & $6.90 \mathrm{E}-13$ & 4.67E-10 & 19.46406954 \\
\hline ARF4 & 1.141135381 & 9.861513946 & 4.629461092 & 7.67E-05 & 0.000380207 & 1.190413168 \\
\hline CYP1B1 & 1.139251767 & 8.983971841 & 6.038927934 & $1.66 \mathrm{E}-06$ & $1.71 \mathrm{E}-05$ & 4.967557162 \\
\hline FGL2 & 1.139176467 & 10.00389177 & 5.396769049 & $9.45 \mathrm{E}-06$ & $6.81 \mathrm{E}-05$ & 3.250007688 \\
\hline TAX1BP1 & 1.137965 & 10.06609394 & 7.996955328 & $1.06 \mathrm{E}-08$ & $3.69 \mathrm{E}-07$ & 9.982636271 \\
\hline DNAJC7 & 1.136922569 & 8.975904344 & 5.350564296 & $1.07 \mathrm{E}-05$ & $7.55 \mathrm{E}-05$ & 3.125849226 \\
\hline SNRPB & 1.13575687 & 10.70918168 & 8.092302578 & 8.37E-09 & $3.11 \mathrm{E}-07$ & 10.21515617 \\
\hline WT1 & 1.132916354 & 9.05457011 & 4.948629513 & $3.21 \mathrm{E}-05$ & 0.000185305 & 2.045480572 \\
\hline SLC13A3 & -1.132662093 & 10.63519462 & -3.356064493 & 0.002291407 & 0.006445268 & -2.099233019 \\
\hline EFNB2 & 1.132430918 & 8.078269009 & 5.104816376 & $2.09 \mathrm{E}-05$ & 0.000130601 & 2.465173592 \\
\hline GATM & -1.132347483 & 9.378659276 & -4.820073926 & $4.56 \mathrm{E}-05$ & 0.000246052 & 1.700515384 \\
\hline $\mathrm{CNIH} 4$ & 1.131683601 & 8.479595575 & 5.273080806 & $1.32 \mathrm{E}-05$ & $8.97 \mathrm{E}-05$ & 2.917571743 \\
\hline EPHX1 & -1.131399427 & 8.499935775 & -2.800395449 & 0.00915647 & 0.020779471 & -3.404434478 \\
\hline SLC12A1 & -1.131269099 & 9.982695474 & -3.262062692 & 0.002913818 & 0.007915227 & -2.327789665 \\
\hline DDX18 & 1.12754023 & 7.44385403 & 6.968940574 & $1.43 \mathrm{E}-07$ & $2.48 \mathrm{E}-06$ & 7.402152136 \\
\hline ALAS1 & 1.125667398 & 9.259205057 & 10.4312198 & $3.86 \mathrm{E}-11$ & $7.26 \mathrm{E}-09$ & 15.5303756 \\
\hline PIPOX & -1.123197227 & 9.810383723 & -3.323828884 & 0.002488819 & 0.006915008 & -2.177924155 \\
\hline TMEM204 & 1.123075986 & 10.94367823 & 5.734623996 & $3.78 \mathrm{E}-06$ & $3.30 \mathrm{E}-05$ & 4.156043341 \\
\hline
\end{tabular}


Huang Z (2019) Novel Pathology-Related Hub Genes in Focal Segmental Glomerulosclerosis

\begin{tabular}{|c|c|c|c|c|c|c|}
\hline gene.symbols & $\log F C$ & AveExpr & ts & P.Value & adj.P.Val & B \\
\hline IFI16 & 1.121716104 & 6.377629496 & 6.221519431 & $1.02 \mathrm{E}-06$ & $1.15 \mathrm{E}-05$ & 5.451564585 \\
\hline FDPS & 1.121519611 & 9.476641456 & 5.462769647 & 7.89E-06 & $5.94 \mathrm{E}-05$ & 3.427285292 \\
\hline ADSL & 1.120968528 & 9.354870139 & 11.7975847 & $2.29 \mathrm{E}-12$ & $1.13 \mathrm{E}-09$ & 18.29564463 \\
\hline C21 orf59 & 1.120241495 & 9.349721825 & 8.079662341 & 8.63E-09 & 3.19E-07 & 10.18440035 \\
\hline PLXDC2 & 1.119961822 & 6.674408432 & 6.694948461 & $2.91 \mathrm{E}-07$ & $4.25 \mathrm{E}-06$ & 6.693470854 \\
\hline IK & 1.119516839 & 11.08344752 & 11.17279646 & $8.10 \mathrm{E}-12$ & $2.26 \mathrm{E}-09$ & 17.06100157 \\
\hline EPB41L5 & 1.119432184 & 8.719882514 & 5.112636291 & $2.05 \mathrm{E}-05$ & 0.000128284 & 2.486196259 \\
\hline PAPOLA & 1.11940591 & 9.203346945 & 6.556215488 & $4.20 \mathrm{E}-07$ & $5.67 \mathrm{E}-06$ & 6.331691821 \\
\hline BABAM1 & 1.118621088 & 9.799168898 & 13.13465146 & $1.78 \mathrm{E}-13$ & $2.09 \mathrm{E}-10$ & 20.77854969 \\
\hline EIF3A & 1.118546997 & 8.851059563 & 7.373548512 & $5.05 \mathrm{E}-08$ & $1.13 \mathrm{E}-06$ & 8.433289332 \\
\hline 10-Sep & 1.11477609 & 7.162778757 & 5.1308438 & $1.95 \mathrm{E}-05$ & 0.000123054 & 2.535146373 \\
\hline METTL3 & 1.114576495 & 9.512185519 & 10.75712554 & $1.93 \mathrm{E}-11$ & 4.32E-09 & 16.21193997 \\
\hline RYBP & 1.114362488 & 8.074681305 & 5.558649075 & $6.08 \mathrm{E}-06$ & $4.84 \mathrm{E}-05$ & 3.684612117 \\
\hline SRSF7 & 1.114068517 & 7.812810523 & 6.78434274 & $2.31 \mathrm{E}-07$ & $3.57 \mathrm{E}-06$ & 6.925561917 \\
\hline SPCS2 & 1.113642182 & 10.67916436 & 10.02665475 & $9.29 \mathrm{E}-11$ & $1.33 \mathrm{E}-08$ & 14.66455361 \\
\hline IL6ST & 1.112439922 & 7.249378474 & 5.2191725 & $1.53 \mathrm{E}-05$ & 0.000101131 & 2.772634323 \\
\hline CASP3 & 1.112233366 & 7.060212477 & 6.02808801 & $1.71 \mathrm{E}-06$ & $1.75 \mathrm{E}-05$ & 4.938747575 \\
\hline SLC22A8 & -1.111645351 & 8.172587127 & -2.906495713 & 0.007078547 & 0.016675257 & -3.164457325 \\
\hline SLC34A1 & -1.111436435 & 8.827172212 & -3.462040019 & 0.001743365 & 0.005105454 & -1.8383435558 \\
\hline SLCO3A1 & 1.110078679 & 7.643092094 & 5.674934307 & 4.44E-06 & $3.76 \mathrm{E}-05$ & 3.996281323 \\
\hline $\mathrm{H} 2 \mathrm{AFZ}$ & 1.109787786 & 10.36972324 & 7.309395678 & $5.94 \mathrm{E}-08$ & $1.29 \mathrm{E}-06$ & 8.271084918 \\
\hline TRAM1 & 1.109674164 & 9.330891829 & 5.475848882 & 7.62E-06 & $5.78 \mathrm{E}-05$ & 3.462403688 \\
\hline CPM & 1.108350817 & 6.344952054 & 4.511146811 & 0.000105862 & 0.000497192 & 0.874975993 \\
\hline SF3B4 & -1.106855958 & 8.447412686 & -11.66922686 & $2.96 \mathrm{E}-12$ & $1.22 \mathrm{E}-09$ & 18.04599558 \\
\hline GPKOW & 1.105821203 & 9.402386711 & 15.05894645 & $6.17 \mathrm{E}-15$ & $2.61 \mathrm{E}-11$ & 24.00537577 \\
\hline COMMD4 & 1.105582864 & 8.633374558 & 9.573721267 & $2.55 \mathrm{E}-10$ & $2.65 \mathrm{E}-08$ & 13.66884399 \\
\hline NKTR & 1.105103578 & 7.436472493 & 6.31627032 & $7.93 \mathrm{E}-07$ & $9.41 \mathrm{E}-06$ & 5.701708637 \\
\hline GZMB & 1.104615964 & 6.213304274 & 4.943201366 & $3.26 \mathrm{E}-05$ & 0.000187539 & 2.030903852 \\
\hline PRKAR1A & 1.103349619 & 9.085496498 & 6.930113803 & $1.58 \mathrm{E}-07$ & $2.69 \mathrm{E}-06$ & 7.302217123 \\
\hline GAR1 & 1.103322681 & 8.867905942 & 11.69566488 & $2.81 \mathrm{E}-12$ & $1.22 \mathrm{E}-09$ & 18.09758328 \\
\hline PCMT1 & 1.10293129 & 9.090122013 & 8.57858399 & $2.58 \mathrm{E}-09$ & $1.32 \mathrm{E}-07$ & 11.38202189 \\
\hline OSBPL1A & 1.101591227 & 7.294578344 & 6.029552935 & $1.71 \mathrm{E}-06$ & $1.75 \mathrm{E}-05$ & 4.942641418 \\
\hline CSNK1A1 & 1.101429726 & 9.136865726 & 8.271107725 & 5.41E-09 & $2.27 \mathrm{E}-07$ & 10.64792844 \\
\hline FRY & 1.101325533 & 7.416761028 & 4.840073415 & $4.32 \mathrm{E}-05$ & 0.000235359 & 1.75414204 \\
\hline ETS2 & 1.10079836 & 9.955899787 & 6.80950633 & $2.16 \mathrm{E}-07$ & $3.38 \mathrm{E}-06$ & 6.990743531 \\
\hline C1QBP & 1.099436575 & 9.443174021 & 7.90432057 & $1.33 \mathrm{E}-08$ & $4.35 \mathrm{E}-07$ & 9.755579866 \\
\hline CAMK1 & 1.098714967 & 7.277320139 & 8.659802769 & 2.12E-09 & $1.16 \mathrm{E}-07$ & 11.57377593 \\
\hline TIGAR & 1.098198376 & 7.2916035 & 5.49588839 & $7.21 \mathrm{E}-06$ & $5.54 \mathrm{E}-05$ & 3.516201816 \\
\hline ELF1 & 1.097652061 & 9.011134077 & 8.423523203 & $3.74 \mathrm{E}-09$ & $1.74 \mathrm{E}-07$ & 11.01342471 \\
\hline PPFIBP1 & 1.096172641 & 6.181551302 & 6.404621461 & $6.27 \mathrm{E}-07$ & $7.83 \mathrm{E}-06$ & 5.934277118 \\
\hline TCF25 & 1.096054149 & 8.091775108 & 6.227690486 & $1.00 \mathrm{E}-06$ & $1.13 \mathrm{E}-05$ & 5.467878422 \\
\hline $\mathrm{CDC} 27$ & 1.095817747 & 8.505153326 & 4.91940844 & $3.48 \mathrm{E}-05$ & 0.000197882 & 1.967020368 \\
\hline SLA & 1.094863831 & 8.203268999 & 6.487175988 & 5.04E-07 & $6.58 \mathrm{E}-06$ & 6.150962717 \\
\hline
\end{tabular}


Huang Z (2019) Novel Pathology-Related Hub Genes in Focal Segmental Glomerulosclerosis

\begin{tabular}{|c|c|c|c|c|c|c|}
\hline gene.symbols & $\log F C$ & AveExpr & ts & P.Value & adj.P.Val & B \\
\hline NEU1 & 1.093178847 & 8.947170302 & 7.96855995 & $1.13 \mathrm{E}-08$ & $3.91 \mathrm{E}-07$ & 9.913156724 \\
\hline MTDH & 1.092673248 & 9.333952516 & 4.191473779 & 0.000251861 & 0.001016156 & 0.029369908 \\
\hline RALYL & -1.091884713 & 8.179522241 & -3.770225925 & 0.0007774 & 0.002597903 & -1.062705647 \\
\hline EGR2 & -1.090102058 & 6.469861827 & -4.641895549 & $7.41 \mathrm{E}-05$ & 0.000369589 & 1.223623989 \\
\hline SELENOW & 1.089407334 & 10.83413383 & 8.564446583 & 2.67E-09 & $1.35 \mathrm{E}-07$ & 11.34855174 \\
\hline DHX35 & 1.088913326 & 7.875257997 & 8.366012273 & 4.30E-09 & $1.94 \mathrm{E}-07$ & 10.87588196 \\
\hline H2AFY & 1.088300954 & 8.945648275 & 7.534738013 & 3.35E-08 & $8.41 \mathrm{E}-07$ & 8.838617254 \\
\hline FEZ2 & 1.088132355 & 9.829802339 & 6.601202262 & $3.73 \mathrm{E}-07$ & 5.13E-06 & 6.449212407 \\
\hline CXCL1 & -1.08797836 & 7.890182363 & -3.583978395 & 0.001269183 & 0.003906784 & -1.534276712 \\
\hline TUBG1 & 1.086695059 & 8.745692451 & 9.151344631 & $6.70 \mathrm{E}-10$ & $5.33 \mathrm{E}-08$ & 12.71491244 \\
\hline EGFR & 1.086214902 & 6.754578363 & 6.745928219 & $2.55 \mathrm{E}-07$ & $3.84 \mathrm{E}-06$ & 6.82592863 \\
\hline DERL1 & 1.086001096 & 6.89012709 & 6.279613636 & 8.74E-07 & $1.01 \mathrm{E}-05$ & 5.605021567 \\
\hline CAV1 & 1.084584181 & 7.441861966 & 7.66312002 & $2.43 \mathrm{E}-08$ & $6.70 \mathrm{E}-07$ & 9.159125496 \\
\hline IDH3G & 1.082946039 & 9.572242915 & 4.996077021 & $2.82 \mathrm{E}-05$ & 0.000166977 & 2.172927883 \\
\hline DDIT4 & 1.082694616 & 9.431563963 & 4.287981287 & 0.000194025 & 0.000818704 & 0.283437599 \\
\hline MT1G & -1.082597887 & 12.96743712 & -5.150025681 & $1.85 \mathrm{E}-05$ & 0.000117877 & 2.586718443 \\
\hline TUBB3 & 1.081470203 & 10.81289795 & 9.271887653 & $5.07 \mathrm{E}-10$ & $4.40 \mathrm{E}-08$ & 12.98966696 \\
\hline $\mathrm{EFHC1}$ & 1.08144924 & 8.498565098 & 9.503313964 & $2.99 \mathrm{E}-10$ & 3.03E-08 & 13.51153807 \\
\hline MPHOSPH8 & 1.081120204 & 8.222430403 & 6.647821917 & $3.30 \mathrm{E}-07$ & 4.67E-06 & 6.570790457 \\
\hline SLC39A6 & 1.080520811 & 8.612275262 & 5.321066886 & $1.16 \mathrm{E}-05$ & 8.09E-05 & 3.046567941 \\
\hline GMPR2 & 1.080419808 & 10.1835269 & 9.982494926 & $1.02 \mathrm{E}-10$ & $1.40 \mathrm{E}-08$ & 14.56870652 \\
\hline PLPP1 & 1.079549675 & 12.22298887 & 4.588629924 & $8.57 \mathrm{E}-05$ & 0.000417251 & 1.081433867 \\
\hline C3AR1 & 1.079533021 & 7.464575983 & 4.520362847 & 0.00010324 & 0.000487288 & 0.899507206 \\
\hline PKP4 & 1.078988705 & 7.219341697 & 4.508110069 & 0.00010674 & 0.000500419 & 0.86689438 \\
\hline SCG5 & 1.078692914 & 6.420091104 & 3.471874341 & 0.001699488 & 0.00500128 & -1.81396971 \\
\hline CNOT8 & 1.078685586 & 8.779292263 & 6.264621562 & $9.09 \mathrm{E}-07$ & $1.05 \mathrm{E}-05$ & 5.565445885 \\
\hline MKNK2 & 1.07867287 & 9.762189026 & 11.32712576 & $5.91 \mathrm{E}-12$ & $1.88 \mathrm{E}-09$ & 17.37056083 \\
\hline ZNF721 & 1.077745797 & 8.69368259 & 4.543383862 & $9.70 \mathrm{E}-05$ & 0.000462503 & 0.960815239 \\
\hline STK32B & -1.076764142 & 8.278102207 & -6.487474074 & $5.03 \mathrm{E}-07$ & $6.58 \mathrm{E}-06$ & 6.151743993 \\
\hline $\mathrm{DAB} 2$ & 1.076679738 & 9.010118077 & 5.160270103 & $1.80 \mathrm{E}-05$ & 0.000115318 & 2.614262168 \\
\hline WDR1 & 1.075060578 & 10.70569774 & 12.48277575 & $6.04 \mathrm{E}-13$ & $4.48 \mathrm{E}-10$ & 19.59432742 \\
\hline DDX50 & 1.072849739 & 10.42516752 & 5.249666541 & $1.41 \mathrm{E}-05$ & $9.46 \mathrm{E}-05$ & 2.854622248 \\
\hline CLDN3 & 1.07236717 & 6.08859028 & 4.843722356 & 4.27E-05 & 0.000233435 & 1.763928086 \\
\hline ZBTB20 & 1.071588517 & 9.17400408 & 4.031253406 & 0.000387637 & 0.001460553 & -0.389561913 \\
\hline ASNA1 & 1.071351132 & 9.062987359 & 4.634014168 & $7.58 \mathrm{E}-05$ & 0.000376438 & 1.202572636 \\
\hline COL4A3BP & 1.069228532 & 7.496292481 & 6.771068462 & $2.39 \mathrm{E}-07$ & $3.67 \mathrm{E}-06$ & 6.891150626 \\
\hline DBT & 1.068894976 & 10.81364504 & 6.479610391 & $5.14 \mathrm{E}-07$ & $6.70 \mathrm{E}-06$ & 6.131130702 \\
\hline KLF6 & 1.068595042 & 8.694058607 & 3.923383883 & 0.000517366 & 0.001851367 & -0.669284058 \\
\hline KLHL20 & 1.068504768 & 7.038412418 & 10.21355215 & $6.17 \mathrm{E}-11$ & $9.83 \mathrm{E}-09$ & 15.06727982 \\
\hline EED & 1.06808641 & 8.464217814 & 7.919227461 & $1.28 \mathrm{E}-08$ & 4.24E-07 & 9.792194251 \\
\hline MTF2 & 1.067468895 & 7.289425208 & 9.731404613 & $1.79 \mathrm{E}-10$ & $2.08 \mathrm{E}-08$ & 14.01867335 \\
\hline USE1 & 1.067373964 & 8.080264229 & 8.78600915 & $1.57 \mathrm{E}-09$ & $9.41 \mathrm{E}-08$ & 11.86994673 \\
\hline DIP2C & -1.064411186 & 8.287020133 & -4.950915171 & $3.19 \mathrm{E}-05$ & 0.000184439 & 2.051618708 \\
\hline
\end{tabular}


Huang Z (2019) Novel Pathology-Related Hub Genes in Focal Segmental Glomerulosclerosis

\begin{tabular}{|c|c|c|c|c|c|c|}
\hline gene.symbols & $\log F C$ & AveExpr & ts & P.Value & adj.P.Val & B \\
\hline GUCY1A3 & 1.064369955 & 8.391717113 & 7.722954073 & $2.09 \mathrm{E}-08$ & $5.98 \mathrm{E}-07$ & 9.307786878 \\
\hline FABP1 & -1.063475899 & 8.139323754 & -2.732116105 & 0.010784021 & 0.023903519 & -3.556239515 \\
\hline NMI & 1.063418627 & 8.913174785 & 6.061674729 & $1.56 \mathrm{E}-06$ & $1.63 \mathrm{E}-05$ & 5.027985704 \\
\hline FNDC3B & 1.062680278 & 7.298362048 & 6.320892845 & 7.83E-07 & $9.33 \mathrm{E}-06$ & 5.713893204 \\
\hline $\mathrm{C} 21$ orf 33 & 1.062481266 & 7.988234956 & 3.425838621 & 0.001914528 & 0.005546208 & -1.92783153 \\
\hline LAP3 & 1.062459662 & 10.15323608 & 5.869684864 & 2.62E-06 & $2.47 \mathrm{E}-05$ & 4.516887066 \\
\hline HSP90B1 & 1.06186157 & 8.503549506 & 5.777879179 & $3.36 \mathrm{E}-06$ & $3.01 \mathrm{E}-05$ & 4.271712257 \\
\hline ING3 & 1.061456364 & 7.638573932 & 4.825058581 & $4.50 \mathrm{E}-05$ & 0.000243541 & 1.71387968 \\
\hline C1QB & 1.061188708 & 6.688390333 & 3.127770653 & 0.004091421 & 0.010523969 & -2.649244412 \\
\hline TMBIM6 & 1.060676668 & 12.20049452 & 4.027508929 & 0.00039155 & 0.001473553 & -0.39930522 \\
\hline GPR161 & 1.059734032 & 6.501724924 & 6.01425427 & $1.78 \mathrm{E}-06$ & $1.81 \mathrm{E}-05$ & 4.901969665 \\
\hline NAA15 & 1.057880748 & 6.432962831 & 6.629466788 & $3.46 \mathrm{E}-07$ & $4.86 \mathrm{E}-06$ & 6.522948198 \\
\hline SULF1 & 1.05757773 & 9.843063851 & 6.231652537 & $9.93 \mathrm{E}-07$ & $1.12 \mathrm{E}-05$ & 5.478350927 \\
\hline WIPI1 & 1.056510973 & 8.27825346 & 6.246765604 & $9.54 \mathrm{E}-07$ & $1.09 \mathrm{E}-05$ & 5.518286309 \\
\hline ZBTB38 & 1.056169824 & 7.302859849 & 7.766411617 & $1.87 \mathrm{E}-08$ & $5.53 \mathrm{E}-07$ & 9.415471696 \\
\hline CSTF1 & 1.055434663 & 7.337081595 & 10.68718219 & $2.23 \mathrm{E}-11$ & 4.83E-09 & 16.06685271 \\
\hline $\mathrm{CX} 3 \mathrm{CR} 1$ & 1.055309203 & 8.117188378 & 3.623156632 & 0.001145417 & 0.003583227 & -1.435762734 \\
\hline NFYC & 1.054756655 & 6.448423523 & 8.20428046 & $6.36 \mathrm{E}-09$ & $2.56 \mathrm{E}-07$ & 10.48668483 \\
\hline APOL3 & 1.054037856 & 10.02998628 & 7.311646662 & $5.91 \mathrm{E}-08$ & $1.28 \mathrm{E}-06$ & 8.276784737 \\
\hline PALMD & 1.053740224 & 7.735488403 & 6.012628847 & $1.78 \mathrm{E}-06$ & $1.81 \mathrm{E}-05$ & 4.897647525 \\
\hline CHTOP & 1.052486772 & 7.220378721 & 6.679260814 & $3.04 \mathrm{E}-07$ & $4.38 \mathrm{E}-06$ & 6.652657347 \\
\hline SEC11A & 1.051884002 & 10.29217746 & 4.251936424 & 0.000213903 & 0.000885124 & 0.188406866 \\
\hline VAMP5 & 1.050721926 & 10.52172068 & 4.438313791 & 0.00012905 & 0.000584474 & 0.681372633 \\
\hline ANKLE2 & 1.05042763 & 7.196105217 & 8.876060405 & $1.27 \mathrm{E}-09$ & $8.10 \mathrm{E}-08$ & 12.07993162 \\
\hline CAP1 & 1.050024945 & 10.95712377 & 7.506067683 & 3.61E-08 & $8.86 \mathrm{E}-07$ & 8.766758041 \\
\hline P4HB & 1.049010802 & 10.47300414 & 4.458270788 & 0.000122236 & 0.000558178 & 0.734373822 \\
\hline PLEKHA1 & 1.048977766 & 7.19454498 & 7.575881532 & $3.02 \mathrm{E}-08$ & $7.84 \mathrm{E}-07$ & 8.941559368 \\
\hline SART1 & 1.047328783 & 8.1137404 & 8.376187797 & 4.19E-09 & $1.90 \mathrm{E}-07$ & 10.90025038 \\
\hline ERBB4 & -1.046679912 & 10.46327143 & -7.702647823 & $2.20 \mathrm{E}-08$ & $6.23 \mathrm{E}-07$ & 9.257386132 \\
\hline CPQ & 1.046010336 & 10.54802267 & 5.912742818 & 2.33E-06 & $2.24 \mathrm{E}-05$ & 4.631713331 \\
\hline FXR1 & 1.045839377 & 7.714915221 & 6.751506073 & $2.51 \mathrm{E}-07$ & $3.80 \mathrm{E}-06$ & 6.840405057 \\
\hline NFASC & -1.043772901 & 11.00079661 & -7.995409742 & $1.06 \mathrm{E}-08$ & $3.70 \mathrm{E}-07$ & 9.978857179 \\
\hline RBM8A & 1.043747898 & 7.545132469 & 4.96501949 & $3.07 \mathrm{E}-05$ & 0.00017886 & 2.089498913 \\
\hline AATF & 1.043262199 & 9.350762714 & 7.721186391 & $2.10 \mathrm{E}-08$ & $6.00 \mathrm{E}-07$ & 9.303401537 \\
\hline RNF146 & 1.042920236 & 7.254295397 & 5.404368353 & $9.25 \mathrm{E}-06$ & $6.72 \mathrm{E}-05$ & 3.270424275 \\
\hline PTK2 & 1.042474572 & 7.441602272 & 7.416573273 & $4.52 \mathrm{E}-08$ & $1.05 \mathrm{E}-06$ & 8.541792951 \\
\hline NSFL1C & 1.042373942 & 7.852911437 & 6.47816252 & $5.16 \mathrm{E}-07$ & $6.71 \mathrm{E}-06$ & 6.127334735 \\
\hline FBXW7 & 1.041338605 & 7.484615862 & 5.840734365 & $2.83 \mathrm{E}-06$ & 2.63E-05 & 4.439622073 \\
\hline NSDHL & 1.040858898 & 7.542287566 & 9.071986684 & $8.06 \mathrm{E}-10$ & $6.00 \mathrm{E}-08$ & 12.53293586 \\
\hline LSM4 & 1.040785139 & 7.644681813 & 7.310557642 & $5.92 \mathrm{E}-08$ & $1.28 \mathrm{E}-06$ & 8.274027254 \\
\hline FBXO9 & 1.038692099 & 7.796898194 & 5.341521258 & $1.10 \mathrm{E}-05$ & $7.71 \mathrm{E}-05$ & 3.101545225 \\
\hline PPARG & 1.037896309 & 6.88201037 & 7.302296857 & $6.05 \mathrm{E}-08$ & $1.30 \mathrm{E}-06$ & 8.253105673 \\
\hline GLT8D1 & 1.037533949 & 8.106135801 & 7.178182333 & $8.31 \mathrm{E}-08$ & $1.64 \mathrm{E}-06$ & 7.937789238 \\
\hline
\end{tabular}


Huang Z (2019) Novel Pathology-Related Hub Genes in Focal Segmental Glomerulosclerosis

\begin{tabular}{|c|c|c|c|c|c|c|}
\hline gene.symbols & $\log F C$ & AveExpr & ts & P.Value & adj.P.Val & B \\
\hline HMGN4 & -1.03747284 & 9.403636016 & -6.593807899 & $3.80 \mathrm{E}-07$ & 5.22E-06 & 6.429909286 \\
\hline PTGER4 & 1.037231193 & 6.884584114 & 5.215070337 & $1.55 \mathrm{E}-05$ & 0.000102088 & 2.761604788 \\
\hline MED6 & 1.035682324 & 5.366963402 & 7.930582401 & $1.25 \mathrm{E}-08$ & $4.18 \mathrm{E}-07$ & 9.820064745 \\
\hline DST & 1.034952212 & 8.875164537 & 5.651911373 & 4.72E-06 & $3.95 \mathrm{E}-05$ & 3.934617402 \\
\hline IFT27 & 1.034430229 & 8.164343121 & 9.736350061 & $1.77 \mathrm{E}-10$ & $2.08 \mathrm{E}-08$ & 14.02958994 \\
\hline MTUS1 & 1.033651385 & 7.914456679 & 6.513891394 & 4.69E-07 & $6.21 \mathrm{E}-06$ & 6.220950438 \\
\hline $\mathrm{ACO} 2$ & 1.033548604 & 10.80339959 & 5.484032163 & 7.45E-06 & $5.68 \mathrm{E}-05$ & 3.484373888 \\
\hline SP3 & -1.031245916 & 9.087202589 & -3.605371867 & 0.001200071 & 0.003731848 & -1.480530029 \\
\hline VDAC3 & 1.030703765 & 8.940345624 & 6.468148347 & $5.30 \mathrm{E}-07$ & $6.84 \mathrm{E}-06$ & 6.101074729 \\
\hline USP39 & 1.029451601 & 8.677413981 & 9.982258621 & $1.02 \mathrm{E}-10$ & $1.40 \mathrm{E}-08$ & 14.56819292 \\
\hline CMTM6 & 1.02805724 & 9.525157136 & 4.774766756 & $5.16 \mathrm{E}-05$ & 0.000273084 & 1.579093631 \\
\hline XYLT1 & -1.027723777 & 8.518221821 & -5.498716221 & $7.16 \mathrm{E}-06$ & $5.52 \mathrm{E}-05$ & 3.523792515 \\
\hline ARHGAP19 & 1.02763613 & 9.56426488 & 7.028513894 & $1.22 \mathrm{E}-07$ & 2.19E-06 & 7.55516027 \\
\hline POLR2E & 1.027421342 & 7.924388244 & 3.308300088 & 0.002589674 & 0.00715863 & -2.215716541 \\
\hline BTG2 & -1.026399219 & 10.23337218 & -7.052038998 & $1.15 \mathrm{E}-07$ & $2.10 \mathrm{E}-06$ & 7.615472284 \\
\hline PRPF19 & 1.026183615 & 8.826847728 & 8.122731764 & 7.77E-09 & $2.96 \mathrm{E}-07$ & 10.2891081 \\
\hline ANKRD11 & 1.025729915 & 7.978900966 & 7.642598687 & $2.56 \mathrm{E}-08$ & $6.94 \mathrm{E}-07$ & 9.108033698 \\
\hline PSMB10 & 1.024330336 & 9.421279003 & 3.339953151 & 0.002388107 & 0.006680164 & -2.138602883 \\
\hline SRPK2 & 1.024123484 & 9.338732967 & 5.693785151 & $4.22 \mathrm{E}-06$ & $3.62 \mathrm{E}-05$ & 4.04675383 \\
\hline COL4A1 & 1.024118647 & 8.992245418 & 5.104326235 & $2.10 \mathrm{E}-05$ & 0.000130711 & 2.46385594 \\
\hline NRN1 & 1.024086017 & 9.095218377 & 4.759145776 & $5.38 \mathrm{E}-05$ & 0.000282366 & 1.537252436 \\
\hline RSRC2 & 1.023758956 & 8.613657235 & 6.01119626 & $1.79 \mathrm{E}-06$ & $1.82 \mathrm{E}-05$ & 4.893838006 \\
\hline RAC1 & 1.0232867 & 11.63257747 & 4.154851659 & 0.000278012 & 0.001103875 & -0.066719657 \\
\hline HADHA & 1.022601138 & 10.74473959 & 6.326166993 & $7.72 \mathrm{E}-07$ & $9.21 \mathrm{E}-06$ & 5.727793185 \\
\hline AUP1 & 1.021101769 & 9.246258609 & 11.719411 & $2.68 \mathrm{E}-12$ & $1.22 \mathrm{E}-09$ & 18.14384431 \\
\hline TXNIP & 1.02026765 & 11.46235662 & 5.062303643 & $2.35 \mathrm{E}-05$ & 0.000143623 & 2.350896021 \\
\hline TUBB & 1.019856466 & 11.1030305 & 5.384868531 & $9.76 \mathrm{E}-06$ & $6.98 \mathrm{E}-05$ & 3.218033023 \\
\hline LPL & -1.019304987 & 9.954464295 & -3.318786443 & 0.002521146 & 0.006987401 & -2.190204228 \\
\hline NPR3 & 1.019147185 & 7.765826952 & 6.380158117 & $6.69 \mathrm{E}-07$ & $8.24 \mathrm{E}-06$ & 5.869949575 \\
\hline GNA11 & 1.018301382 & 7.135455751 & 3.567078203 & 0.001326501 & 0.00405132 & -1.576653085 \\
\hline ARPC1A & 1.018110026 & 10.05733879 & 5.427722254 & $8.68 \mathrm{E}-06$ & $6.39 \mathrm{E}-05$ & 3.333160252 \\
\hline TSPAN4 & 1.017903455 & 9.153133398 & 3.286599685 & 0.002737228 & 0.007501373 & -2.268400912 \\
\hline HNRNPA3 & 1.017675658 & 7.627507212 & 5.584619489 & $5.67 \mathrm{E}-06$ & $4.57 \mathrm{E}-05$ & 3.75426261 \\
\hline JUN & -1.01630629 & 10.14683512 & -8.526608216 & $2.92 \mathrm{E}-09$ & $1.45 \mathrm{E}-07$ & 11.25883533 \\
\hline COBL & -1.016074994 & 9.359404055 & -7.163224111 & $8.64 \mathrm{E}-08$ & $1.68 \mathrm{E}-06$ & 7.899664761 \\
\hline EIF3B & 1.015917612 & 7.916407277 & 7.295506558 & $6.16 \mathrm{E}-08$ & $1.32 \mathrm{E}-06$ & 8.235902161 \\
\hline COPS6 & 1.01571967 & 10.73984087 & 6.871235397 & $1.84 \mathrm{E}-07$ & $3.00 \mathrm{E}-06$ & 7.150356983 \\
\hline PTPRO & -1.015461858 & 12.12826016 & -4.113981359 & 0.000310368 & 0.001211407 & -0.173730401 \\
\hline ZFP36 & -1.015055803 & 9.582243452 & -6.92601257 & $1.59 \mathrm{E}-07$ & $2.71 \mathrm{E}-06$ & 7.2916514 \\
\hline BUD23 & 1.014932236 & 9.485752254 & 6.221938523 & $1.02 \mathrm{E}-06$ & $1.15 \mathrm{E}-05$ & 5.452672596 \\
\hline PBLD & -1.014740962 & 10.58094791 & -3.724016801 & 0.000878415 & 0.002881032 & -1.180450248 \\
\hline SNTB2 & 1.014417654 & 7.961457348 & 6.282527181 & $8.67 \mathrm{E}-07$ & $1.01 \mathrm{E}-05$ & 5.612710524 \\
\hline CTDSPL & 1.01439347 & 10.43635804 & 4.266936434 & 0.000205397 & 0.000857252 & 0.22793438 \\
\hline
\end{tabular}


Huang Z (2019) Novel Pathology-Related Hub Genes in Focal Segmental Glomerulosclerosis

\begin{tabular}{|c|c|c|c|c|c|c|}
\hline gene.symbols & $\log F C$ & AveExpr & ts & P.Value & adj.P.Val & B \\
\hline RNF7 & 1.01409318 & 9.590065207 & 9.476640922 & $3.18 \mathrm{E}-10$ & $3.19 \mathrm{E}-08$ & 13.45176623 \\
\hline PTPRN2 & 1.013187332 & 9.817821348 & 9.100558946 & $7.54 \mathrm{E}-10$ & $5.75 \mathrm{E}-08$ & 12.59855544 \\
\hline ZBTB18 & -1.012739735 & 9.549857266 & -6.564108062 & 4.11E-07 & $5.59 \mathrm{E}-06$ & 6.352323976 \\
\hline SERINC3 & 1.012252699 & 9.515098643 & 5.004169961 & $2.76 \mathrm{E}-05$ & 0.000164243 & 2.194671288 \\
\hline EPHA4 & 1.012059148 & 7.692051937 & 8.221126207 & 6.11E-09 & $2.48 \mathrm{E}-07$ & 10.52738762 \\
\hline EXPH5 & -1.011374294 & 9.267532038 & -6.395702776 & $6.42 \mathrm{E}-07$ & 7.99E-06 & 5.910831112 \\
\hline SLC14A1 & 1.010232523 & 8.216419273 & 4.925155609 & 3.42E-05 & 0.00019565 & 1.982449863 \\
\hline AMPH & -1.008900528 & 7.734124024 & -3.684116541 & 0.000975864 & 0.003135087 & -1.281735767 \\
\hline HLA-J & 1.00871551 & 10.19609554 & 8.597452642 & $2.46 \mathrm{E}-09$ & $1.28 \mathrm{E}-07$ & 11.42665058 \\
\hline PRMT5 & 1.007933207 & 9.428092233 & 7.939886786 & $1.22 \mathrm{E}-08$ & 4.11E-07 & 9.842889558 \\
\hline PON2 & 1.007800835 & 10.09079366 & 3.81949425 & 0.000682209 & 0.002328987 & -0.936662463 \\
\hline FBXW2 & 1.007654936 & 7.868340028 & 7.861953607 & $1.48 \mathrm{E}-08$ & 4.63E-07 & 9.651359007 \\
\hline STX18 & 1.006898222 & 10.37920307 & 10.5061697 & $3.28 \mathrm{E}-11$ & $6.42 \mathrm{E}-09$ & 15.68836623 \\
\hline MRPL9 & 1.00575951 & 8.56785435 & 10.39823871 & 4.14E-11 & 7.62E-09 & 15.4606155 \\
\hline NCOA1 & 1.005421619 & 9.05825609 & 6.916782293 & $1.63 \mathrm{E}-07$ & $2.76 \mathrm{E}-06$ & 7.267865336 \\
\hline EIF3D & 1.004960463 & 10.76774901 & 9.588105769 & $2.47 \mathrm{E}-10$ & $2.61 \mathrm{E}-08$ & 13.70089836 \\
\hline ZNF45 & 1.004939996 & 5.556368284 & 6.771883066 & $2.38 \mathrm{E}-07$ & 3.67E-06 & 6.893262879 \\
\hline RBL2 & 1.004173461 & 7.21346767 & 8.632505051 & 2.27E-09 & $1.21 \mathrm{E}-07$ & 11.50942809 \\
\hline РTP4A2 & 1.003941839 & 7.140081341 & 8.279182405 & 5.30E-09 & $2.24 \mathrm{E}-07$ & 10.66737061 \\
\hline CXADR & 1.003893604 & 9.64625798 & 3.484927272 & 0.001642901 & 0.004854007 & -1.781577202 \\
\hline TTC37 & 1.001622392 & 7.444769781 & 5.465907256 & 7.83E-06 & $5.91 \mathrm{E}-05$ & 3.435710333 \\
\hline ATP6V0E2 & -1.001198901 & 9.83254098 & -7.451280242 & 4.14E-08 & $9.82 \mathrm{E}-07$ & 8.629154547 \\
\hline UROD & 1.001043527 & 9.325183612 & 16.03116183 & $1.28 \mathrm{E}-15$ & $9.51 \mathrm{E}-12$ & 25.49653811 \\
\hline THSD7A & 1.001019085 & 9.626288581 & 3.889413906 & 0.00056643 & 0.001995535 & -0.756941013 \\
\hline NFIL3 & -1.000765264 & 8.473403841 & -5.219220674 & $1.53 \mathrm{E}-05$ & 0.000101131 & 2.77276385 \\
\hline POLR2A & -1.000463151 & 8.643383429 & -6.408934128 & $6.20 \mathrm{E}-07$ & 7.77E-06 & 5.945612006 \\
\hline
\end{tabular}

